\title{
The Declaration on Human Rights and Climate Change: a new legal tool for global policy change
}

\author{
Kirsten Davies* \\ Senior lecturer, Macquarie Law School, Macquarie University, Australia
}

Sam Adelman

Associate Professor, School of Law, University of Warwick, UK

\section{Anna Grear}

Professor of Law and Theory, Cardiff University, UK

Catherine lorns Magallanes

Reader in Law, Victoria University of Wellington, New Zealand

Tom Kerns

Director, Environment and Human Rights Advisory; Professor Emeritus of Philosophy, North Seattle College, USA

\author{
S Ravi Rajan \\ Professor of Environmental Studies, University of California, Santa Cruz, USA
}

The Declaration on Human Rights and Climate Change responds to the profound crisis of human hierarchies now characterizing the climate crisis. The Declaration, initiated prior to the 2015 COP 21 meeting by scholars from the Global Network for the Study of Human Rights and the Environment (GNHRE), is one of a convergence of initiatives reflecting the need to understand human rights as intrinsically threatened by climate change. This article introduces the Declaration, the necessity for it, its philosophical and legal background and its support by contemporary cases providing evidence of the escalating legal need for such a tool. A key aim of the Declaration is to trace out a potential normative approach for establishing responsibility towards the planet and redressing unevenly distributed vulnerabilities and climate injustices while recognizing that it is vital that respect for human rights should be understood as an indispensable element of any adequate approach to

* The Global Network for the Study of Human Rights and the Environment would like to thank all those from different backgrounds and cultures across the world who assisted in the drafting process, disseminating information and responding to the original Draft Declaration, and those involved in the drafting and editing of the final version. Special thanks are extended to the scholars who translated the Draft and the final Declaration into multiple languages to enable its global dissemination. This initiative had no funding and was driven by volunteers who generously gave their time. The authors of this article would also like to thank Dr Kerri Woods Lecturer in Political Theory, University of Leeds, UK for her early comments on a draft, and to thank Thomas Riddell for his research assistance. 
climate change. The Declaration strives to offer a compelling level of ethical appeal, as well as to be legally literate and philosophically rigorous. The drafting process engaged scholars and communities from across the world, prioritized indigenous involvement, and drew on indigenous ontologies and epistemologies. Newer philosophical approaches such as new materialist understandings of lively materiality also informed the drafting process. Accordingly, the language of the Declaration creates space for non-Western ways of seeing and being as well as responding to insights emerging from new scientific understandings of the world.

Keywords: declaration, climate change, human rights, Anthropocene, climate injustice, rights of nature

\section{INTRODUCTION}

The Intergovernmental Panel on Climate Change (IPCC) warns that 'human influence on the climate system is clear, and recent anthropogenic emissions of greenhouse gases are the highest in history: Recent changes to the Earth's climate have had widespread impacts on human and natural systems'. ${ }^{1}$ The IPCC report makes it clear that climate change exacerbates existing risks and creates new threats to human-nature systems that are not evenly distributed, with the poor and disadvantaged disproportionately affected. ${ }^{2}$ The report stresses the importance of the dual approach of mitigation and adaptation, coupled with '[e]ffective decision-making to limit climate change and its effects .... ${ }^{3}$ The climate crisis creates immense and apparently intractable challenges. With the global population predicted to reach 8.5 billion in $2030,9.7$ billion in 2050 and 11.2 billion by the end of the century, ${ }^{4}$ it is clear that anthropogenic global warming is generating unprecedented pressures on the planet that require imaginative new approaches to law, politics and justice. The scale and urgency of such challenges has led a growing number of thinkers and activists to insist that human rights should form a central component of all responses to climate change. ${ }^{5}$ This

1. Intergovernmental Panel on Climate Change, Climate Change 2014: Synthesis Report. Contribution of Working Groups I, II and III to the Fifth Assessment Report of the Intergovernmental Panel on Climate Change, RK Pachauri and LA Meyer (eds), Geneva, Switzerland, 2. 2. See, eg, the Intergovernmental Panel on Climate Change, Climate Change 2014: Synthesis Report: Summary for Policymakers (IPCC, Geneva 2014) 31: 'Climate change exacerbates other threats to social and natural systems, placing additional burdens particularly on the poor (high confidence)' and 'Climate change is a threat to sustainable development' $<$ https://www. ipcc.ch/report/ar5/syr/> accessed 16 March 2017.

3. Pachauri and Meyer, above (n 1).

4. United Nations, Department of Economic and Social Affairs, Population Division (2015), 'World Population Prospects: The 2015 Revision, Key Findings and Advance Tables'.

5. See J Von Doussa, A Corkery and R Charters, 'Human Rights and Climate Change' (2007) 14 Australian International Law Journal 161; OW Pedersen, 'The Janus-Head of Human Rights and Climate Change: Adaptation and Mitigation' (2011) 80 Nordic International Journal of Law 403; P Tschakert and M Machado, 'Gender Justice and Rights in Climate Change Adaptation: Opportunities and Pitfalls' (2012) 6(3) Journal of Ethics and Social Welfare 275; Oxfam International, 'Climate Wrongs and Human Rights' (Briefing Paper) (September 2008); A Maguire and J McGee, 'A Universal Right to Shape Responses to a Global Problem? The Role of SelfDetermination in Guiding the International Legal Response to Climate Change' (2017) 26 Review of European, Comparative and International Environmental Law 54. 
convergence of opinion builds upon existing claims that there is an inextricable link between human rights and environmental integrity. ${ }^{6}$

Today there is a widespread consensus in international law and public policy concerning the universality, indivisibility and interdependence of human rights and the dependence of all life forms on a healthy ecological and harmonious planetary system. ${ }^{7}$ Climate science details the threats that climate change poses to the livelihoods and well-being of present and future human generations and ecosystems, while policy approaches increasingly recognize the growing social risks of climate-change-driven vulnerabilities. $^{8}$

International climate negotiations have sought to develop mitigation and adaptation responses commensurate with the climate-related harms affecting various communities, with deliberations focusing on how to apportion costs and responsibilities between states and other actors in a fair manner. ${ }^{9}$ Climate justice mandates the importance of recognizing that climate change impacts are unevenly and unfairly distributed in that the historical emissions of industrialized nations disproportionally affect the poor and vulnerable, including women and children, small island developing states, indigenous peoples, less developed countries, future generations and innumerable non-human organisms and living systems. ${ }^{10}$ The IPCC predicts that $20-30$ per cent of plant and animal species surveyed will be threatened by extinction if the average global temperature increases by more than $1.5-2.5^{\circ} \mathrm{C}$ above preindustrial levels. This will lead to biodiversity loss and related impacts on all species, including humans, in terms of health, food, shelter and water security. ${ }^{11}$ In the short period since the IPCC

6. The concept of human rights was enshrined in the United Nations Charter, and re-affirmed in several documents, including the Universal Declaration of Human Rights, the International Covenant on Economic, Social and Cultural Rights, the International Covenant on Civil and Political Rights, the Vienna Declaration and Program of Action of the World Conference of Human Rights, the United Nations Declaration on the Rights of Indigenous Peoples, and the Nagoya Protocol. The idea of human responsibility for the natural environment has also been widely ratified in several international agreements and instruments of international environmental law including the Stockholm Declaration of the United Nations Conference on the Human Environment, United Nations Framework Climate Change Convention, the Convention on Biological Diversity, the World Charter for Nature, United Nations Convention on the Law of the Sea, and the Rio Declaration on Environment and Development.

7. United Nations Convention on the Law of the Sea (Montego Bay) 10 December 1982 (entered into force 16 November 1994) 21 ILM 1261, preamble; Convention on Biological Diversity (Rio de Janeiro) 5 June 1992, 1760 UNTS 143 (entered into force 29 December 1993) preamble; United Nations Framework Convention on Climate Change (New York) 9 May 1992, 1771 UNTS 107 (entered into force 21 March 1994) preamble.

8. T Honkonen, 'The Principle of Common but Differentiated Responsibility in Post-2012 Climate Negotiations' (2009) 18(3) Review of European Community \& International Environmental Law 257, 257.

9. See C Voigt and F Ferreira, "Dynamic Differentiation": The Principles of CBDR-CR, Progression and Highest Possible Ambition in the Paris Agreement' (2016) 5(2) Transitional Environmental Law 285; L Rajamani, 'The Changing Fortunes of Differential Treatment in the Evolution of International Environmental Law' (2012) 88(3) International Affairs 605.

10. Francesco N Tubiello et al., 'Carbon Financial Mechanisms for Agriculture and Rural Development: Challenges and Opportunities along the Bali Roadmap' (2009) Climatic Change, editorial essay.

11. Intergovernmental Panel on Climate Change (IPCC) Summary for Policymakers. In: Climate Change (2007): Impacts, Adaptation and Vulnerability. Contribution of Working Group II to the Fourth Assessment Report of the Intergovernmental Panel on Climate Change. 
reported, the state of the world's biodiversity has worsened ${ }^{12}$ and predictions of future biodiversity losses have become even more dire. ${ }^{13}$

In light of such clear interconnections between climate-related and other forms of vulnerability, scholars from different disciplines, along with practitioners and an increasing number of judges, argue that the fulfilment of human rights is linked to and contingent upon a secure, healthy and ecologically sound environment. ${ }^{14}$ There is growing recognition that non-human species and living systems are affected by climate harms and that human beings have a duty of stewardship to respect and protect them. ${ }^{15}$

The Declaration on Human Rights and Climate Change was developed in 2015-16 by members of the Global Network for the Study of Human Rights and the Environment (GNHRE). The drafters aimed to address the low profile of human rights in negotiations in the UN Framework Convention on Climate Change (UNFCCC). The GNHRE approach endorses the need for a Declaration that highlights the central importance of human rights as a powerful meta-ethical idea with widespread international appeal for the development of policies on adaptation, mitigation, loss and damage, and climate justice.

This article elaborates on the text of the Declaration and reflects upon sources in law, public policy, science, philosophy, history and other disciplines in support of its central tenets. We aim to demonstrate the moral case for the Declaration and to showcase the legal and political precedents upon which it is broadly based. First, we address the issue of intra-generational equity, noting how anthropogenic climate change intensifies both existing and future injustices and inequalities. ${ }^{16}$ Second, we explore the threats posed by climate change to inter-generational equity and to the rights of future generations. The third stage of the analysis explores the rights of non-human entities and argues that human beings have duties and obligations as stewards of nature and of other living beings. We argue that other species - and arguably ecosystems - have intrinsic rights to protection. ${ }^{17}$ The fourth section of our argument examines the question of direct responsibility and its application in international human rights law to nation states, corporations and non-state actors in respect of climatic harms. The conviction underpinning the inclusion of the latter in the Declaration is that climate change creates potentially irreversible impacts that demand urgent consideration of new forms of state and non-state accountability and liability.

12. WWF, Living Planet Report 2016, stated that non-human vertebrates declined by 58 per cent between 1970 and 2012. Available at <http://wwf.panda.org/about_our_earth/all_publications/ 1pr_2016/> last accessed 27 March 2017.

13. R McKie, 'Biologists Think 50\% of Species will be Facing Extinction by the End of the Century', The Guardian (25 February 2017) <https://www.theguardian.com/environment/2017/ feb/25/half-all-species-extinct-end-century-vatican-conference> accessed 27 March 2017.

14. A Costello et al., 'Managing the Health Effects of Climate Change' (2009) 373 The UCL Lancet Commissions; S Humphreys and M Robinson (eds), Human Rights and Climate Change (Cambridge University Press, Cambridge 2010); S Adelman, 'Human Rights and Climate Change', in G DiGiacomo (ed), Human Rights: Current Issues and Controversies (University of Toronto Press, Toronto 2016) 411.

15. Jianguo Liu et al., 'Complexity of Coupled Human and Natural Systems' (2007) 317 (5844) Science 1513; Driscoll et al., 'Science and Society: The Role of Long-Term Studies in Environmental Stewardship' (2012) 62(4) BioScience 354.

16. S Kverndokk, E Nævdal and L Nøstbakken, 'The Trade-off between Intra- and Intergenerational Equity in Climate Policy' (2014) 69 European Economic Review 40, 41.

17. See also LJ Kotzé and PV Calzadilla, 'Somewhere between Rhetoric and Reality: Environmental Constitutionalism and the Rights of Nature in Ecuador' (2017) Transnational Environmental Law 1-33 (doi:10.1017/S2047102517000061). 


\section{DEVELOPING THE DRAFT DECLARATION}

In October 2015, ahead of COP 21, 13 members of GNHRE located around the world, ${ }^{18}$ developed the Draft Declaration on Human Rights and Climate Change. ${ }^{19}$ The drafting process was completed in three weeks and released for comment two weeks prior to the commencement of COP 21. Through media releases, marketing materials and calls issued through social media, professional and personal networks, and the GNHRE website, people from across the world were invited to offer their responses to the draft. To aid this process the Draft Declaration was translated into eight languages. ${ }^{20}$

Responses poured in, and the drafting process responded inclusively to the range of suggestions offered. The project was not funded and was driven by volunteer scholars in each phase. The volunteers did not adhere to any particular political or economic influences or agendas, and the drafting process was a collective, collaborative and cooperative process uninhibited by institutional limitations. The Declaration was developed with the primary aim of putting human rights at the heart of policies and activities to combat anthropogenic warming.

During the drafting phase, the GNHRE sought endorsements and responses from the global community. The public exhibition phase of the work, which ended on 19 February 2016, elicited, as noted, a range of responses. In particular, the scholars involved sought the input of indigenous peoples. The open nature of the approach adopted provided the epistemic space for a wide range of people from a range of cultural backgrounds to inform the final text.

\subsection{Content of the Declaration}

The full text of the Declaration is available at the end of this article. However, a few brief introductory comments to orient the reader are in order before we discuss some of the issues and underlying concerns reflected by it.

The preamble to the Declaration sets out its normative and factual context, priorities and values, and refers to the alternative ontologies and epistemologies mentioned above and to be discussed more fully below. The Declaration contains 24 principles addressing the negative dimensions of climate change impacts on human rights. These principles

18. Drafting group members: Anna Grear, Professor of Law and Theory, Director of the GNHRE, Cardiff Law School, Wales, UK; Louis J Kotzé, Research Professor, North-West University, South Africa, Deputy-Director, GNHRE; Dr Tom Kerns, Director, Environment and Human Rights Advisory; Professor Emeritus of Philosophy, North Seattle College, USA; Dr Kirsten Davies, Senior Lecturer, Macquarie Law School, Macquarie University, Australia; Dr Sam Adelman, Associate Professor of Law, School of Law, University of Warwick, UK; Deva Prasad M, Assistant Professor of Law, National Law School of India University, Bangalore, India; Joshua C Gellers, Assistant Professor of Political Science and Public Administration, University of North Florida, USA; Dr Kerri Woods, Lecturer in Political Theory, University of Leeds, UK; Engobo Emeseh, Senior Lecturer in Law, Aberystwyth University, UK; Catherine Iorns Magallanes, Senior Lecturer in Law, Victoria University of Wellington, New Zealand; Dr John Pearson LLB, LLM, Lecturer in Environmental Law and Human Rights, University of Manchester, UK; Ravi Rajan, Professor, Department of Environmental Studies, University of California, Santa Cruz, USA; Dr Silja Klepp, Senior Researcher/Acting Managing Director, Sustainability Research Center, University of Bremen, Germany.

19. Available at <http://gnhre.org/gnhre-draft-declaration/> last accessed 8 May 2017.

20. Spanish, German, Italian, Polish, Norwegian, Amharic, Mandarin and Persian. 
are divided into three broad categories: substantive entitlements (Articles 1-8), procedural entitlements (Articles 9-15) and normative obligations (Articles 16-24).

The substantive entitlements are designed to address the harms caused by climate change and to indicate the possibilities of non-anthropocentric approaches to human rights and climate injustices. For example, Article 3 declares that 'all human beings, animals and living systems have the right to a secure, healthy and ecologically sound Earth system', making non-human beneficiaries the explicit recipient of rights-based consideration.

The procedural entitlements address the differential distribution of vulnerabilities to be discussed throughout this article. These entitlements reflect, among other things, the importance of providing avenues of hearing to climate-affected communities. Climate injustice, in the Declaration's understanding, urgently necessitates epistemic justice in response. Such epistemic injustice must, in our view, include embracing new ontological foundations, and epistemic justice, in turn, is fundamental to achieving the worldview shift so urgently needed in response to the climate crisis and to its related injustices. Procedural rights and entitlements, and adequate fora for participatory deliberation and adjudication are thus fundamental to the search for appropriate responses to climate change as a crisis of intra- and inter-species hierarchies.

Finally, the Declaration recognizes the need for the adoption of clear normative obligations. Along with accountability, imposing responsibilities through a nuanced and textured anthropo-deontology (especially addressing those most responsible for climate change and with the greatest capacity to deal with the injustices it causes) is urgently needed, we believe, in response to the challenges of anthropogenic climate change. The obligations listed in the Declaration are a response to the hierarchical impositions of historical and contemporary injustices, not least forms of epistemic injustice fundamental to the 'othering' or 'invisibilizing' of indigenous peoples and other vulnerable groupings. This section of the Declaration, accordingly, deliberately frames obligations in the form of duties placed upon states, corporations and individuals alike - duties that directly address climate-harming activities, the need to make reparations and to provide resources for those harmed, and procedural duties designed to promote accountability, democracy and transparency.

\section{THE BROAD, TRANSFORMATIVE PURPOSE OF THE DECLARATION: ADDRESSING CORE THEMES}

The Declaration was sensitively and inclusively drafted to promote a rights-based approach to climate change and climate justice that does not take liberal rights as its point of departure or sole focus, but instead seeks to integrate non-Western ontologies and epistemologies. A central aim of the Declaration is to provide an articulation between Western and non-Western legal thinking and traditions in an ecology of knowledges that values different epistemologies equally. ${ }^{21}$

21. We note the inappropriateness of terminology such as 'the environment', 'natural capital' and 'environmental services' arising from anthropocentric, dualistic and hierarchical epistemologies of mastery and hubris. We are uneasy with such terminology because it reflects the ontology of human centrality and the peripheral, object-status of the living order; we use it only to reticulate with existing legal and policy discourses in language that makes the Declaration, and this discussion, accessible and familiar. On ecology of knowledges, see B de Sousa Santos, 'Beyond Abyssal Thinking: From Global Lines to Ecologies of Knowledges' (2007) Review (Fernand Braudel Center) 45-89. 


\subsection{Intra-generational rights and climate justice}

The need to recognize intra-generational rights and to grapple with the questions of justice that haunt them is becoming ever more stark as the climate crisis unfolds. While it is clear that the number of environmental catastrophes will increase in future, the impacts of climate change will not necessarily always provide horrific headlines and images of hurricanes, droughts and wildfires. More commonly, and perhaps problematically from the point of view of ensuring appropriate responses to them, climate impacts will also be cumulative, unspectacular and all too easily accepted as part of mundane quotidian reality. Climate science indicates that - suddenly or gradually existing vulnerabilities will be exacerbated as anthropogenic climate change reinforces drivers of impoverishment and inequality, and undermines the adaptive capacity of vulnerable populations. ${ }^{22}$ The 2014 IPCC report warned that:

Climate change will have a disproportionate impact on poor developing countries compared to the expected net effects in developed regions - due to a combination of more severe climatic effects in areas that are already vulnerable today, coupled to poor overall capacity to adapt to the projected threats. ${ }^{23}$

Slowly and incrementally, crops are failing, coral reefs are dying, species are shifting their geographic ranges and seasonal activities, melting permafrost is damaging water resources and infrastructure, and rising sea levels are undermining low elevation coastal dwellings. ${ }^{24}$ Many species are becoming extinct and livelihoods are vanishing. Increases in the frequency and intensity of ecosystem disturbances such as droughts, windstorms, fires and pest outbreaks will result in cataclysms that exacerbate these slower moving trends, destabilizing states and generating conflicts that result in mass migrations. ${ }^{25}$

As already noted, climate change exacerbates underlying patterns of vulnerability and axes of discrimination and exploitation. This pattern affects a wide range of activities and spheres of human action. Agriculture, for example, is increasingly threatened by desertification, which is happening in places as diverse as Chad and China, while rising sea levels threaten low-lying delta states such as Bangladesh and Vietnam. ${ }^{26}$ Amongst the most vulnerable and exposed populations are those in the Arctic and in low-lying island nations such as Tuvalu and the Maldives. Global warming has increased the exposure of such populations to infectious, vector-borne diseases and

22. See C Pettengel, 'Climate Change Adaptation: Enabling People Living in Poverty to Adapt' (Oxfam Research Report) (April 2010); J Ensor, 'Adaptation and Resilience in Vanuatu' (Oxfam Research Report) (November 2015); MB Soares, AS Gagnon and RM Doherty, 'Conceptual Elements of Climate Change Vulnerability Assessment: A Review' (2009) 4 International Journal of Climate Change Strategies and Management 6.

23. Tubiello et al., above (n 10); Pachauri and Meyer, above (n 1).

24. Pachauri and Meyer, above (n 1) 51.

25. Ibid 54; M Robinson, 'Foreword', in Climate Change and Human Rights: A Rough Guide (International Council on Human Rights Policy, Switzerland, 2008); ML Miranda et al., 'The Environmental Justice Dimensions of Climate Change' (2011) 4(1) Environmental Justice 17. 26. Collectif Argos, Climate Refuges (MIT Press, Cambridge MA 2010; K Davies, 'Kastom, Climate Change and Intergenerational Democracy: Experiences from Vanuatu', in WL Filho (ed), Managing Climate Change in the Asia-Pacific Region (Springer International Publishing 2015); Edith Brown Weiss, 'Climate Change, International Equity and International Law' (2008) 9 Vermont Journal of Environmental Law 615, 616-27. 
mental illness. ${ }^{27}$ Similar patterns of unevenly distributed vulnerability and exposure are equally clear within developed states. Disadvantaged populations tend to live in places that are more susceptible to climate risks, which are heightened by the socio-economic construction of vulnerability that undermines resilience, health and well-being. ${ }^{28}$ It is evident that the geographies of climate injustice and vulnerability remain closely correlated with historical patterns of socio-economic, racial and gender injustice.

The negative effects of climate change profoundly affect the achievement and protection of a wide range of rights. Social and economic rights such as the rights to water, food, sanitation, health and housing are affected by climate change, which exacerbates the harms that hinder their protection. ${ }^{29}$ The right to life is challenged by climate change through increased hunger and malnutrition - especially in children - and increased disease and injuries from a wide range of climate-induced effects. ${ }^{30}$ Such effects are likely to cause political instability, threaten human security and adversely affect human rights, including political participation and self-determination. These effects on rights intensify the discrimination suffered by marginalized groups such as indigenous peoples.

\subsubsection{Indigenous peoples}

Coupled with their marginalization in an international legal system historically shaped by colonialism and by persistent structural inequalities, climate change presents a particularly profound threat to indigenous peoples whose cultural and physical survival depends upon traditional access to land and nature. The cosmology, culture and customary law of indigenous communities are inseparable from their relationship with nature. ${ }^{31}$ Indigenous people in many parts of Australia, for instance, have a body of social rules and practices referred to as 'the dreaming' that are believed to

27. CC Macpherson, S Bidaisee and CNL Macpherson, 'Environmental Harms in Distant Polar Regions and Small Island Developing States', in CC Macpherson (ed), Bioethical Insights into Values and Policy (Springer International Publishing, 2016) 127.

28. SM Wilson, R Richard, L Joseph and E Williams, 'Climate Change, Environmental Justice, and Vulnerability: An Exploratory Spatial Analysis' (2010) 3(1) Environmental Justice 13; SB Shonkoff, R Morello-Frosch, M Pastor and J Sadd, 'Minding the Climate Gap: Environmental Health and Equity Implications of Climate Change Mitigation Policies in California' (2009) 2(4) Environmental Justice 173.

29. See, generally, IPCC AR5, WGII Report Climate Change 2014: Impacts, Adaptation and Vulnerability, available at <http://www.ipcc.ch/report/ar5/wg2/> accessed 27 March 2017. All aspects of food security will likely be affected, including direct access to food production and quality and price stability. The quality and quantity of available fresh water will diminish, especially in areas already subject to water stress, but also climate change will increase the number and extent of such areas. The reduction in available water will significantly affect all areas of life, including security (ibid 232). Extreme weather events and rising sea levels will affect water and sanitation infrastructure (see, eg, ibid 556). Extreme weather events and sea level rise will diminish the availability of housing, as will more intense heat waves and fires, and all of these will harm human health, particularly those with least resilience (ibid 742); see JH Knox, 'Human Rights Principles and Climate Change', in CP Carlarne, KR Gray and R Tarasofsky (eds), Oxford Handbook of International Climate Change Law (Oxford University Press, Oxford 2016).

30. Ibid.

31. See, generally, B Thom, 'Coast Salish Senses of Place: Dwelling, Meaning, Power, Property and Territory in the Coast Salish World' (DPhil Thesis, McGill University 2005); K Bauer, 
derive from ancestral beings who underwent journeys through which they transformed their bodies into features of the waterways, land and sea. In so doing, these beings gave life to peoples, bestowed places upon them and gave them local knowledge. ${ }^{32}$ In addition, many indigenous populations develop their knowledge over time through oral traditions and experiential learning, passing it on to younger generations through rituals like ceremony, music and art, and practices such as hunting and harvesting. ${ }^{33}$ Indigenous peoples therefore require access to their land to maintain their cultural knowledge, history and collective identity. The impacts of climate change threaten to disrupt this access, as does an international legal system rooted in colonialism and in a Eurocentric perception of nature as separate from humankind - of nature as either a threat to the social order or a refuge from it. ${ }^{34}$

Large numbers of the world's indigenous peoples inhabit the Arctic and small island developing states. The Arctic has a population of about 4 million, in which there are over 30 different indigenous peoples, and small island developing states combined have a population of over 60 million. ${ }^{35}$ Despite contributing little to greenhouse gas emissions, these populations are particularly vulnerable to climatic harms and face the brunt of the immediate climate change impacts. ${ }^{36}$ In addition, their size and geographic locations mean that such populations have limited economic and political influence and low adaptive capacities.

Land rights naturally form a critical bulwark against the climate injustices confronting indigenous peoples. Colonial-based Western legal systems have historically undermined many indigenous communities' attempts to secure land rights. However, inroads have been made in international agreements such as the International Covenant on Civil and Political Rights (ICCPR), the International Covenant on Economic, Social and Cultural Rights (ICESCR), the Nagoya Protocol and the Convention on Biological Diversity.

Both the ICCPR and the ICESCR recognize in common Article 1 that 'All peoples have the right of self-determination by virtue of which they freely determine their political status and freely pursue their economic, social and cultural development' ${ }^{37}$ There has also been some legal recognition of the important role that culture and traditional knowledge play in biodiversity conservation. Article 8(j) of the Convention on Biological Diversity encourages parties to 'respect, preserve and maintain the knowledge, innovations and practices of indigenous and local communities

'Protecting Indigenous Spiritual Values' (2007) 19(3) Peace Review 343; M Blakeney, 'Protecting the Spiritual Beliefs of Indigenous Peoples - Australian Case Studies' (2013) 22(2) Pacific Rim Law and Policy Journal 391.

32. See L Jones, Encyclopedia of Religion (Macmillan Reference USA, Detroit 2005); T Swain, A Place for Strangers: Towards a History of Australian Aboriginal Being (Cambridge University Press, Cambridge 1993).

33. M Dieguez Leuzinger and K Lyngard, 'The Land Rights of Indigenous and Traditional Peoples in Brazil and Australia' (2016) 13(1) Revista de Direito Internicional, Brasilia, 419.

34. M Colchester, Salvaging Nature: Indigenous Peoples, Protected Areas and Biodiversity Conservation (UNRISD, Geneva 1994) 1.

35. Macpherson, Bidaisee and Macpherson, above (n 27).

36. Ibid.

37. International Covenant on Civil and Political Rights, adopted and opened for signature, ratification and accession by General Assembly resolution 2200A (XXI) of 16 December 1966 (entered into force 23 March 1976) Article 1; International Covenant on Economic, Social and Cultural Rights, adopted and opened for signature, ratification and accession by General Assembly resolution 2200A (XXI) of 16 December, 1966 (entered into force 3 January 1976) Article 1. 
embodying traditional lifestyles relevant for the conservation and sustainable use of biological diversity'.38

Indigenous legal strategies centering on human rights are increasingly in evidence. The Inuit peoples of Alaska, for example, have attempted to establish links between violations of their human rights, the environmental harms they are experiencing and the emissions of particular companies or states. In 2005, the Inuit presented a petition to the Inter-American Commission on Human Rights Seeking Relief from Violations Resulting from the Global Warming Caused by the Acts and Omissions of the United States. ${ }^{39}$ While they did not win, their case successfully reframed what had been viewed exclusively as an environmental problem as a human rights issue. ${ }^{40}$

Despite the urgency of recognizing the ways in which the human rights of indigenous peoples are threatened by climate harms, the existential threat posed by climate change to such communities is insufficiently acknowledged. One particularly illustrative (and notorious) case concerns the village of Kivalina, a community under threat that brought legal action in the case of The Native Village of Kivalina $v$ ExxonMobil et $a l .{ }^{41}$ The village of Kivalina, an Inupiat village of approximately 400 people in Alaska, is threatened by the melting of Arctic sea ice. The community took legal action against ExxonMobil for climate-change-related loss of their Inupiat cultural home and territorial integrity. The melting of the sea ice had denuded the protection Kivalina once enjoyed from winter storms, and the applicants alleged that '[c]ritical infrastructure is imminently threatened with permanent destruction. If the entire village is not relocated soon, the village will be destroyed' ${ }^{42}$ However, as Westra points out, the most significant aspect of the case was not really considered:

namely, the effect on the cultural and territorial rights of the Kivalina Natives. Even if the US Government spends the necessary $\$ 400$ million required to 'relocate' the inhabitants of the Native village, their land and their religious and cultural rights will be irrevocably lost, especially as most Aboriginal peoples' lives are inextricably linked to the area they have always occupied. Removed from their traditional areas, even if the individual lives of citizens are saved, their survival as peoples - in fact as those specific peoples of Kivalina - is no longer possible. ${ }^{43}$

For indigenous peoples, the threat of climate change goes to the heart of their existence as a people, with all that that implies for their right to exist as the people they are. They are thus serially marginalized by failure to take the impacts upon their geospatial locations seriously, by the cultural genocide implicit in that failure and by the continuing subordination of their indigenous ontologies, epistemologies and agencies, even in legal forms of protection ostensibly aimed at their 'inclusion'.

While developments such as the emergence of discourses on biocultural rights hold out hope of much-needed recognition of indigenous agency and of unique indigenous forms

38. Convention on Biological Diversity, opened for signature 5 June 1992, 1760 UNTS 79 (entered into force 29 December 1993) Article 36.

39. Inuit Circumpolar Council Canada, Petition to the Inter-American Commission on Human Rights Seeking Relief from Violations Resulting from Global Warming Caused by Acts and Omissions of the United States, 7 December 2005.

40. Adelman, above (n 14) 423.

41. Native Village of Kivalina v ExxonMobil et al., CP Cal 2008, no C08-01138 SBA.

42. Ibid para 4.

43. L Westra, 'Climate Change and the Human Right to Water' (2010) 1(2) Journal of Human Rights and the Environment 161, 174. 
of environmental stewardship, ${ }^{44}$ even these developments come freighted with ambiguities and complexities concerning the construction of indigeneity and the tendency of Eurocentric law and thought to marginalize (and instrumentalize) indigenous perspectives and practices. ${ }^{45}$ Thus, just as indigenous peoples who have sustained and conserved 'natural' environments for centuries have been forcefully transferred from restricted protected areas, so their traditional knowledge is now at risk of a form of cultural appropriation. Those driven from their traditional lands (such as the indigenous peoples of the Arctic and small island developing states) lose their cultural identities in the process.

\subsubsection{The rights of women and girls}

The impacts of climate change are not gender neutral ${ }^{46}$ and will continue to reflect this fact because climate change affects the availability of natural resources, labour and income opportunities. Gendered social roles, gender-based inequalities in decisionmaking, control over resources, allocation of household tasks, access to technology and legal barriers against women that inhibit them from responding to climate change's impacts all carry climate justice implications. ${ }^{47}$ This has major consequences for their families and communities.

It is well documented that women and girls, who form the majority of the world's poor, ${ }^{48}$ are particularly vulnerable to climate change because they play a central role in providing household nutrition that is dependent on natural resources. ${ }^{49}$ Women and girls are primarily responsible for access to food and water and support agricultural development through soil and water conservation, reforestation and crop domestication. ${ }^{50}$ As UNICEF points out:

Girls and young women are often especially vulnerable to the negative impacts of climate change, for a number of reasons. In many societies, girls and young women carry out tasks such as collecting water that put them in close contact with the natural world. In many rural

44. KS Bavikatte and T Bennett, 'Community Stewardship: The Foundation of Biocultural Rights' (2015) 6(1) Journal of Human Rights and the Environment 7.

45. G Sajeva, 'Rights with Limits: Biocultural Rights - between Self-determination and Conservation of the Environment' (2015) 6(1) Journal of Human Rights and the Environment 30. 46. A Brody, J Demetriades and E Esplen, Gender and Climate Change: The Physical Science Basis, Contribution of Working Group 1 to the Fourth Assessment Report of the Intergovernmental Panel on Climate Change (Cambridge University Press, Cambridge 2007); I Dankelman, Gender and Climate Change: An Introduction (Routledge, London 2012); Rachel Masika, Gender, Development, and Climate Change (Oxfam 2002).

47. Food and Agriculture Organization of the United Nations, The State of Food and Agriculture (FAO 2016) 49; N Ahmad, L El-Fatal, E Pehu, P Poutiainen and M Vyzaki, Gender, Agriculture, and Climate Change (The World Bank 2014); Valerie Nelson, Gender, Generations, Social Protection \& Climate Change: A Thematic Review (Overseas Development Institute 2011); PTA Huynh and BP Resurreccion, 'Women's Differentiated Vulnerability and Adaptations to Climate Related Agricultural Water Scarcity in Rural Central Vietnam' (2004) 6(3) Climate and Development 226.

48. United Nations, Economic and Social Council, Achieving Sustainable Development and Promoting Development Cooperation: Dialogues at the Economic and Social Council (United Nations Publications 2008) 235.

49. G Ziervogel and PJ Ericksen, 'Adapting to Climate Change to Sustain Food Security' (2010) 1 WIREs Climate Change 529.

50. World Bank, Gender in Agriculture Sourcebook (The World Bank 2009) 64. 
areas of Africa, for example, girls are the ones who are most often responsible for collecting fuel, wood and safe water. ${ }^{51}$

In the multiple and mutating contexts of climate change, women in developing countries, whose livelihoods overwhelmingly depend on the natural environment, are forced to work harder, to travel further to secure resources, and are threatened by a loss in income and depleted harvests (often their sole source of income) ${ }^{52}$ If crops fail due to climatic conditions, it is easier for men to leave in search of employment, whereas women are generally left struggling to feed the family and prepare for the next crop failure. Unequal access to resources and to decision-making is exacerbated by climate change. Structural constraints, such as lack of education and cultural restrictions, further inhibit the ability of many of these women to engage in entrepreneurial activities that might alleviate this cycle. ${ }^{53}$

According to UNICEF, 'It is estimated that 65 per cent of those who will be affected by climate-related disasters every year in the next decade will be women and children'. ${ }^{54}$ Women farmers in developing countries currently produce between 45 and 80 per cent of global food. ${ }^{55}$ Approximately two-thirds of the female labour force in developing countries (and more than 90 per cent in many African countries) is engaged in agricultural work - a sector particularly vulnerable to the impacts of climate change. ${ }^{56}$ The cumulative impact of these facts reveals a gendered fault-line in the geographies of climate injustice that also has implications for the rights of future generations. The intra-generational aspects of climate-related human rights are thus intrinsically linked to women's rights - and gender is an essential component of climate justice.

In terms of future solutions-based strategies, it is essential to note that women's participation in environmental and natural resource management has the potential to alleviate a number of environmentally degrading human practices, such as energy intensity, deforestation and population growth likely to increase the build-up of greenhouse gas emissions. ${ }^{57}$ It is therefore essential that climate change should not lead to women in developing countries being further marginalized as this will weaken the adaptive capacity of these countries.

The reflexive nature of the link between the position of women and girls, indigeneity, climate and vulnerability is clear but not adequately addressed in policy terms. In 2001, at COP 7, the Samoan delegate called for more equitable representation of women in the UNFCCC. Although representation subsequently improved, there is no guarantee that women in poverty will be represented ${ }^{58}$ or that women's indigenous knowledge will be included in policymaking. As Fatma Denton has noted, 'a great

51. UNICEF, Climate Change Take Action Now (2004) 33.

52. F Denton, 'Climate Change Vulnerability, Impacts, and Adaptation: Why does Gender Matter?' (2010) 20(2) Gender and Development 12.

53. C Chitsike, 'Culture as a Barrier to Rural Women's Entrepreneurship: Experience from Zimbabwe' (2000) 8(1) Gender and Development 71.

54. UNICEF, Climate Change and Environmental Education (2013) <http://www.unicef.org/ education/bege_61668.html> accessed 15 April 2017.

55. Food and Agriculture Organization of the United Nations (FAO), Women and Food Security, FAO FOCUS (2009) <http://www.fao.org/FOCUS/E/Women/Sustin-e.htm> accessed 15 April 2017.

56. Ibid.

57. Denton, above (n 52) 11.

58. Ibid 12 . 
deal of lip-service has been paid to women's indigenous knowledge of environmental management and soil preservation, [but] little is being done to integrate this local knowledge into mainstream policy'. ${ }^{59}$ She argues that:

Women are already paying huge prices for globalisation, economic depression, and environmental degradation. Climate change is likely to worsen their already precarious situation, and leave them even more vulnerable. More efforts should be made to give climate negotiations a people-centred approach, and to give women their rightful place within the sustainable development circle. Women have taken a keen interest in environmental resource management, and have generated a great deal of wealth in terms of indigenous environmental knowledge, which needs to have its value to medicine and other fields acknowledged. ${ }^{60}$

\subsubsection{The rights of children}

Climate change is predicted to impact heavily upon children, especially those in developing countries. ${ }^{61}$ Children disproportionately suffer the health burdens of environmental stressors such as extreme weather events and a lack of clean water. Children are the first to suffer malnutrition when food is scarce. ${ }^{62}$ If families are separated in emergencies, children are the ones who are less able to fend for themselves and who need greater assistance and protection. ${ }^{63}$ When disruptions occur to family life the education of children is quickly disrupted. ${ }^{64}$

The predicted effects of climate change mean that children are likely to be the most affected and most in need of protective attention. The rights of children feature strongly in contemporary climate justice concerns. For example, the Convention on the Rights of the Child includes a right to an education that involves respect for the natural environment. ${ }^{65}$ States are obliged to recognize that adequate provision for the health of the child includes but is not limited to recognizing the "dangers and risks of environmental pollution' ${ }^{\prime 66}$ and the role of 'environmental sanitation'. ${ }^{67}$ While the express right to a viable environmental future does not appear in any international human rights instruments and the Convention does not explicitly mention climate change, environmental rights are included in the constitutions of at least

59. Ibid.

60. Ibid 18 .

61. See, eg, UNICEF, Climate Change and Children (2007), available at $<$ www.unicef.org/ publications/files/Climate_Change_and_Children.pdf>; UNICEF, Unless We Act Now - the

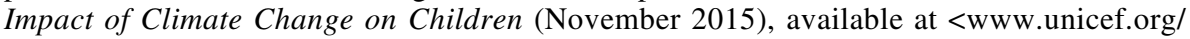
publications/files/Unless_we_act_now_The_impact_of_climate_change_on_children.pdf $>$; UNICEF UK, No Place to Call Home: Protecting Children's Rights when the Changing Climate Forces them to Flee (2017), available at <https://downloads.unicef.org.uk/wp-content/ uploads/2017/04/No-Place-To-Call-Home.pdf >.

62. See J Currie and O Deschênes, 'Children and Climate Change: Introducing the Issue' (2016) 26 The Future of Children 3.

63. See R Akresh, 'Climate Change, Conflict, and Children' (2016) 26 The Future of Children 51.

64. Ibid.

65. Convention on the Rights of the Child (New York) (adopted 20 November 1989, in force 2 September 1990) 29 ILM 1340, Article 29(1)(e). This right however, is tempered by the lack of communicative capacity. Article 12 aims to address this, with the caveat that this opinion is given 'due weight in accordance with the age and maturity of the child'.

66. Ibid Article 24(2)(c).

67. Ibid Article 24(2)(e). 
92 countries; ${ }^{68} 125$ constitutions contain some mention of the environment, while 75 constitutions articulate the right to a clean, healthy safe environment. ${ }^{69}$ Environmental rights are also central to emergent theories of global environmental governance, such as Weston and Bollier's paradigm of green governance. ${ }^{70}$ Children's rights are implicit in all such developments, in which the rights of future generations also feature. The link is relatively intuitive because, as Brown Weiss argues, children are the embodiment of future generations. ${ }^{71}$

The Convention on the Rights of the Child does not expressly mention the rights of future generations but their protection is logically implied. The preamble states that 'the child, by reason of his [sic] physical and mental immaturity, needs special safeguards and care, including appropriate legal protection, before as well as after birth'. ${ }^{72}$ This reference to legal protection before birth has been interpreted to include future generations, and the Convention is arguably a potential stepping stone to a strengthening recognition of the legal rights of future generations to a viable future - a normative argument that links the rights of children to considerations of climate and environmental justice. ${ }^{73}$ This link is made more explicit by the fact that children and future generations have a right to inherit a healthy planet and that adults in the present generation have a corresponding duty to preserve and protect the quality of such shared resources. ${ }^{74}$ Brown Weiss maintains that adults need to 'develop further the normative framework for protecting the environmental interest of children and through them the interest of future generations'. ${ }^{75}$

\subsection{Inter-generational rights}

According to Brown Weiss, 'each generation has a right to receive the planet in no worse condition than that of previous generations, to inherit comparable diversity in natural and cultural resources, and to have equitable access to use and secure benefits from the planet'. ${ }^{76}$ Her formulation encapsulates a rich combination of

68. For a summary of recent research on constitutional environmental rights see $C$ Jeffords and JC Gellers, 'Constitutionalizing Environmental Rights: A Practical Guide' (2017) Journal of Human Rights Practice 1.

69. C Jeffords 'Constitutional Environmental Human Rights: A Descriptive Analysis of 142 National Constitutions', in Lanse Minkler (ed), The State of Economic and Social Human Rights: A Global Overview (Cambridge University Press, Cambridge 2013) 329, 333; JR May and E Daly, Global Environmental Constitutionalism (Cambridge University Press, Cambridge 2015) 274.

70. BH Weston and D Bollier, Green Governance: Ecological Survival, Human Rights, and the Law of the Commons (Cambridge University Press, Cambridge 2013).

71. E Brown Weiss, 'In Fairness to Future Generations' (1990) 32(3) Environment: Science and Policy for Sustainable Development 7, 8 .

72. Convention on the Rights of the Child (New York) (adopted 20 November 1989, in force 2 September 1990) 29 ILM 1340, preamble.

73. Ibid; see, generally, C Dillard, 'Prospective Parents and the Children's Rights Convention' (2010) 25(3) American University International Law Review 485; see Just Planet, 'States' Obligations to Stabilise the Climate for the Life, Survival and Development of Children and Future Generations' (Submission to the UN Committee on the Rights of the Child, 2016) $<$ http://www.ohchr.org/Documents/HRBodies/CRC/Discussions/2016/JustPlanet.pdf $>$.

74. Brown Weiss, above (n 71) 9.

75. Ibid.

76. Ibid 10 . 
biocultural interests and points directly to the important notion of inter-generational equity.

In the field of international environmental governance, the principle of intergenerational equity was referred to in the influential 1987 United Nations report Our Common Future, otherwise known as the Brundtland Report. ${ }^{77}$ The report defines sustainable development as that which 'meets the needs of the present without compromising the ability of future generations to meet their own needs' ${ }^{78}$ The principle has direct implications for human rights duties. If we think of human rights as part of the legacy that current generations bequeath to future generations, there is an obligation on those currently alive not to undermine the ability of their descendants to ensure that the rights of the most vulnerable are protected. ${ }^{79}$ The serious impacts of climate change on resources that future generations will need undermine the sustainability of their future enjoyment of human rights, but issues of inter-generational injustices are poorly represented in international, national and regional policies on climate change. $^{80}$

Nevertheless, the important acknowledgement that the environment does not exist for the sole benefit of current generations and growing awareness that the environmental inheritance of future generations cannot be taken for granted represent a potentially significant shift: the comparatively recent emergence of environmental rights or a human right to a clean and healthy environment is premised upon the idea that there is an obligation on each generation to conserve the environment for future generations. ${ }^{81}$ The right is often referred to as a third generation right, ${ }^{82}$ while the related concept of common concern for humankind implies the existence of a common responsibility that involves the whole of the international community. ${ }^{83}$

The principle of common concern for humankind is also referred to in the context of climate change in the preamble to the Convention on Biological Diversity (CBD). ${ }^{84}$ The principle is linked to inter-generational equity by the Rio Declaration, the UNFCCC and the Paris Agreement. ${ }^{85}$ The United Nations Report of the Expert

77. United Nations, Our Common Future - Brundtland Report (Oxford University Press, Oxford 1987), 43.

78. Ibid.

79. A Gosseries, 'On Future Generations' Future Rights' (2008) 16(4) Journal of Political Philosophy 446.

80. M Göpel and M Arhelger, 'How to Protect Future Generations' Rights in European Governance' (2010) 10(1) Intergenerational Justice Review 1, 4.

81. Brown Weiss, above (n 71) 7.

82. J Morgan-Foster, 'Third Generation Rights: What Islamic Law Can Teach the International Human Rights Movement' (2005) 8 Yale Human Rights and Development Law Journal 67; J Downs, 'Healthy and Ecologically Balanced Environment: An Argument for a Third Generation Right' (1993) 3(2) Duke Journal of Comparative \& International Law 351.

83. L Horn, 'The Implications of the Concept of Common Concern of a Human Kind on a Human Right to a Healthy Environment' (2004) 1 Macquarie Journal of International and Comparative Environmental Law 233, 235.

84. Convention on Biological Diversity (Rio de Janeiro) (adopted 5 June 1992, in force 29 December 1993) 31 ILM 822, preamble.

85. United Nations, Conference on Environment and Development (UNCED) Rio de Janeiro, Brazil, 3 to 14 June 1992, Annex I, Rio Declaration on Environment and Development, UN Doc A/CONF.151/26 (Vol. I) Principle 2; United Nations Framework Convention on Climate Change (New York) 9 May 1992, 1771 UNTS 107 (entered into force 21 March 1994) preamble; Conference of the Parties, United Nations Framework Convention on Climate Change, Report of the Conference of the Parties on its Twenty First session, held in Paris from 
Group Meeting on Identification of Principles of International Law for Sustainable Development notes that the word 'humankind' itself 'establishes a link between present and future generations', ${ }^{86}$ but the principle is not yet a general rule of international law, ${ }^{87}$ despite its potential to evolve into a principle of customary international law.

Despite their limitations, such developments are vital steps in the creation of a conceptual space for new critiques and epistemologies. It is important to recall that neither the 1948 Universal Declaration of Human Rights ${ }^{88}$ nor the 1950 European Convention on Human Rights ${ }^{89}$ make express mention of the environment or of future generations. The relationship between human rights and the environment was initially established in 1968 by the UN General Assembly, which expressed concern about how the environment could affect the enjoyment of human rights. ${ }^{90}$ This was later translated into overt recognition of the relationship between human rights and the environment by the United Nations in the 1972 Stockholm Declaration. ${ }^{91}$ Though not legally binding, several of the principles articulated in the Declaration are now so widely accepted that some consider them to be part of customary international law. ${ }^{92}$ Since 1972, many international instruments have included mention of an inter-generational right to a viable future in a variety of ways. ${ }^{93}$ Further notable references to the right were articulated during the 1992 United Nations Conference on

30 November to 13 December 2015 - Addendum - Part 2: Action taken by the Conference of the Parties at its Twenty First Session, UN Doc FCCC/CP/2015/10/Add.1 (29 January 2016), Decision 1/CP.21 'Adoption of the Paris Agreement', Proposal by the President.

86. United Nations, 'Report of the Expert Group Meeting on Identification of Principles of International Law for Sustainable Development', Geneva, Switzerland, 26-8 September 1995, prepared by the Division for Sustainable Development for the Commission on Sustainable Development, Fourth Session 18 April-3 May 1996, 84.

87. The same arguably applies to sustainable development, which is a non-enforceable norm, rather than a rule. See P Sands, J Peel and R MacKenzie, Principles of International Environmental Law (Cambridge University Press, Cambridge 2012) 206, 234.

88. Universal Declaration of Human Rights (adopted 10 December 1948 UNGA Res 217 A (III) (UDHR)).

89. European Convention for the Protection of Human Rights and Fundamental Freedoms (Rome) (adopted 4 November 1950, in force 3 September 1953), 213 UNTS 221.

90. UNGA Res 2398(XXIII) (3 December 1968), 'Problems of the Human Environment'.

91. United Nations, Declaration of the United Nations Conference on the Human Environment (Stockholm, 1972) UNDoc A/CONF/48/14/REV. 1.

92. T Allen, 'The Philippine Children's Case: Recognizing Legal Standing for Future Generations' (1993) 6 The Georgetown International Environmental Law Review 713. Section 6 of the preamble, along with Principles 1 and 2 specifically mention future generations and the need to protect the environment. Section 6 regards the protection of the environment for future generations as an imperative goal: "[t]o defend and improve the human environment for present and future generations has become an imperative goal for mankind [sic]' while Principles 1 and 2 see the protection of the environment as humanity's 'responsibility' for the benefit both of 'present and future generations'.

93. The 1972 Convention Concerning the Protection of the World Cultural and Natural Heritage (World Heritage Convention), the 1973 Convention on International Trade in Endangered Species of Wild Fauna and Flora, the 1982 United Nations World Charter for Nature, the 1992 Convention on the Trans-boundary Effects of Industrial Accidents, the 1994 United Nations Convention to Combat Desertification in those Countries Experiencing Serious Drought and/ or Desertification, Particularly in Africa, and the 1996 United Nations Conference on Human Settlements (the Habitat Agenda or the Istanbul Declaration on Human Settlements). 
Environment and Development, also known as the Earth Summit. ${ }^{94}$ The summit produced three important documents that refer to inter-generational equity: the Rio Declaration, Agenda 21 and the Forest Principles. These documents are non-binding but lay out important principles of international environmental law and became the inspiration, if not the basis, for later treaties and court decisions involving the inter-generational right to a viable future. ${ }^{95}$

However, important critiques remain. For example, inter-generational justice as currently conceived is stubbornly anthropocentric. Understanding the environment as a site for the fulfilment of human needs is profoundly counterproductive and produces many climate injustices. Sustainable development itself has been extensively criticized for fostering illusions of endless economic growth on a finite planet, cloaking 'business as usual' beneath forms of greenwashing, and inhibiting meaningful structural change - not least due to its anthropocentrism. ${ }^{96}$ This is readily apparent in Principle 3 of the Rio Declaration, which mandates that ' $[\mathrm{t}]$ he right to development must be fulfilled so as to equitably meet developmental and environmental needs of present and future generations'. ${ }^{97}$ The terminology of 'environmental needs' implies an 'environment' subjugated to human needs.

Agenda 21, an action plan for the implementation of sustainable development by the United Nations, national governments and multilateral organizations, exhorts states to adopt sustainable development practices with the purpose of 'protecting the resource base and the environment for the benefit of future generations' ${ }^{98}$ Agenda 21 recognizes that the needs of future generations may refer to any or all of the following aims and realizations: (a) that the present generation must avoid passing on environmental burdens to future generations; ${ }^{99}$ (b) that assisting developing countries is in the common interest of mankind, which includes future generations; ${ }^{100}$ and (c) that the 'cost of inaction' could 'narrow the choices of future generations'. ${ }^{101}$ The future generations in view are always clearly human and the environment is conceptualized as a 'resource base' to meet human needs. This pervasive anthropocentrism is also recognizable, albeit in a more culturally inclusive way, in the Forest Principles, a document exhorting the conservation and sustainable development of forests. Principle 2(b) reminds the international community of the need for sustainable management of forests to meet the different needs of present and future generations: 'Forest resources and forest lands should be sustainably

94. United Nations, Conference on Environment and Development (UNCED) Rio de Janeiro, Brazil, 3 to 14 June 1992.

95. See E Rehbinder, 'UNCSD/RIO+20: Contribution to the Development of Environmental Law' (2012) 42(4/5) Environmental Policy and Law 2010; E Brown Weiss, 'The Evolution of International Environmental Law' (2011) 54 Japanese Yearbook of International Law 1.

96. See H Kopnina, 'The Victims of Unsustainability: A Challenge to Sustainable Development Goals' (2015) 23(2) International Journal of Sustainable Development \& World Ecology 113; P England, 'Problems and Prospects for the Implementation of Sustainable Development in Developing Countries: A Critique of the Brundtland Report' (1993) 2(2) Griffith Law Review 147.

97. Ibid Principle 3.

98. United Nations, Conference on Environment and Development (UNCED), Rio de Janeiro, Brazil, 3 to 14 June 1992, Agenda 21, UN Doc A/CONF.151/26 (Vol. II) section 8.7.

99. Ibid section 8.31.

100. Ibid section 33.3.

101. Ibid section 33.4 . 
managed to meet the social, economic, ecological, cultural and spiritual needs of present and future generations'. ${ }^{102}$

As well as its normative place in these documents, the inter-generational right to a sustainable future is also mentioned in a range of other international instruments, although these references are generally hortatory rather than binding. Notable exceptions to the generally 'soft' status of the right in international documents are the UNFCCC ${ }^{103}$ and the CBD. ${ }^{104}$ Under international treaty law, not only are both instruments binding, they also expressly mention future generations in their preambles. The UNFCCC explicitly mandates that ' $[\mathrm{t}]$ he Parties should protect the climate system for the benefit of present and future generations of humankind', ${ }^{105}$ while the CBD refers to future generations in the context of sustainable use: "Sustainable use" means the use of components of biological diversity in a way and at a rate that does not lead to the long-term decline of biological diversity, thereby maintaining its potential to meet the needs and aspirations of present and future generations'. ${ }^{106}$

The resolutely anthropocentric nature of the discourse of inter-generational equity haunts the formulation of the right to a sustainable future by imposing key limitations. While the inclusion of the concept of future generations in the substantive text of binding international instruments is a step forward for inter-generational equity as a customary principle of international law and opens an important discursive space, it is far from clear that this is a straightforwardly transformative development. Given the wide-ranging critiques of both the CBD and the UNFCCC for effectively locking the future into anthropocentric market rationality, the meaning and implications of the right of future generations remain open questions. Core strategies for the protection of the planet and its biodiversity are now thickly layered with financial strategies and circumscribed by the dominance of market values that fail to internalize ecological complexity. Climate strategies do not adequately consider tipping points, positive feedback loops or ecological limits, and do not adequately take into consideration other forms of valuation that have emerged in social and environmental thought over the past few decades. ${ }^{107}$ As a result inter-generational justice as presently conceived - as an anthropocentric impulse - may be further muted in its

102. United Nations, Conference on Environment and Development (UNCED), Rio de Janeiro, Brazil, 3 to 14 June 1992, Non Legally Binding Authoritative Statement of the Principles for a Global Consensus on the Management, Conservation and Sustainable Development of all Types of Forests, UN Doc A/CONF.151/26 (Vol. III), Principle 2(b).

103. United Nations Framework Convention on Climate Change (New York) (adopted 9 May 1992, in force 24 March 1994) 1771 UNTS 107.

104. Convention on Biological Diversity (Rio de Janeiro) (adopted 5 June 1992, in force 29 December 1993) 31 ILM 822, preamble.

105. United Nations Framework Convention on Climate Change (New York) (adopted 9 May 1992, in force 24 March 1994) 1771 UNTS 107, Article 3(1).

106. Convention on Biological Diversity (Rio de Janeiro) (adopted 5 June 1992, in force 29 December 1993) 31 ILM 822, Article 2.

107. H-J Koch, D König, J Sanden and R Verheyen, Legal Regimes for Environmental Protection: Governance for Climate Change and Ocean Resources (Brill, Leiden 2015); TW Luke, 'Environmentality as Green Governmentality', in E Darier (ed), Discourses of the Environment (Blackwell, Oxford 1999); TW Luke, 'On Environmentality: Geo Power and Eco-Knowledge in Discourses of Contemporary Environmentalism' (1995) 31(2) Cultural Critique 57; C Corson and KI MacDonald, 'Enclosing the Global Commons: The Convention on Biological Diversity and Green Grabbing' (2012) 39(2) Journal of Peasant Studies 263. 
justice-aspiring implications by neoliberal assumptions at odds with radical concern for alternative future histories of climate justice.

\subsubsection{Inter-generational equity in case law}

Notwithstanding such critical anxieties, the principle of inter-generational equity has the potential, as does customary international law, to defend the rights of future human generations in international and domestic courts. Given this potential, there might be an opening, if humans are understood to be ontologically inseparable from nature, that a 'weak anthropocentrism' could facilitate the emergence of more transformative normative practices. We consider such possibilities below, after considering relevant case law as it currently stands.

The degree to which the principle of inter-generational equity is accepted in a given legal context will be influenced by the extent to which inter-generational rights are integrated into national constitutions, codes and legislation as well as international agreements. Crucially, the current effectiveness of the principle is strongly influenced by preceding legal rulings recognizing it.

Two important examples of the recognition of inter-generational justice suggest the possibility for alternative values to influence legal outcomes. The first of these cases is Oposa v Factoran. ${ }^{108}$ In 1992, a group of 43 Filipino children representing themselves and future generations filed a class action against the Philippines government's Secretary of the Department of Environment and Natural Resources concerning the management of public forest land, 100000 hectares of which were being logged each year. The children sought to prevent further deforestation, arguing that continued logging would infringe their right to a healthy environment under the Filipino Constitution and that deforestation would cause irreparable harm to themselves and to future generations. In the first instance, the case was overturned on the grounds that the petitioners, as children, were not deemed to have the requisite legal standing to litigate. ${ }^{109}$ This ruling was overturned by the Philippines' Supreme Court on the grounds of inter-generational responsibility and with regard to statistical evidence presented concerning the extent of forest cover necessary to maintain a healthy environment for present and future generations. ${ }^{110}$ The court added that the human rights of self-preservation and self-perpetuation being defended in the case pre-dated all governments and constitutions and should not need to be written into constitutions as such rights are fundamental to humankind. ${ }^{111}$ While the case was on appeal, a new law was passed to protect all remaining virgin forest within national protected areas. $^{112}$

The second case is Massachusetts $v$ EPA. ${ }^{113}$ In 2007, 12 states and several cities in the United States filed a suit against the Environmental Protection Agency (EPA) for failing to regulate $\mathrm{CO}_{2}$ and other greenhouse gas (GHG) emissions under the Federal

108. Oposa v Factoran, 224 SCRA 792 (1993); reprinted in 33 ILM 173 (1994).

109. Ibid.

110. Ibid.

111. Ibid.

112. Some critics maintain that providing children with 'standing to sue for future generations' does not serve any practical purpose: D Gatmaytan, 'The Illusion of Intergenerational Equity: Oposa v. Factoran as Pyrrhic Victory' (2002) 15 The Georgetown International Environmental Law Review 457, 475.

113. Massachusetts v EPA 549 US 497, 127 S.Ct. 1438, 167 L.Ed.2d. 248 (2007). 
Clean Air Act. The complaint was based on potential risks to the Massachusetts coastline and to the welfare of the state's citizens caused by rising sea levels associated with climate change. The Court found that the plaintiff successfully demonstrated injury based on the actual and imminent consequences of unregulated emissions and that the EPA was responsible for this injury by neglecting its regulatory responsibility. The Court ruled that the EPA must review a request made by Massachusetts to regulate omissions. ${ }^{114}$ Despite the fact that the demonstrated harms were based on future predictions and that the risk of catastrophic damage was marginal, the Court found that the redress sought had the potential to reduce or to slow the effects of climate change and that this provided sufficient grounds upon which to affirm the plaintiffs' standing against the EPA. ${ }^{115}$ The case constitutes important recognition that GHGs are air pollutants, and the judgment may have influenced the decision in Gray v Macquarie Generation. ${ }^{116}$ In the latter case, the applicant challenged the Director-General of New South Wales' opinion that an environmental assessment was valid on the grounds that the assessment did not expressly take into account the issue of inter-generational equity. ${ }^{117}$ The Court held that the issue of inter-generational equity should have been included in the basis of the environmental assessment. ${ }^{118}$

When considered alongside the fact that the concept of inter- and intra-generational equity has now been incorporated into several international treaties, these cases indicate growing acceptance and possibly the crystallization of the principle of inter-generational equity in customary international law. ${ }^{119}$ This acceptance opens an aperture, it is suggested, for future development of the principle. Ultimately however, the future of the principle depends upon the strength and willingness of judiciaries and legislatures to embrace it, and the degree to which market rationality and profit seeking can be subordinated to longer term societal and ecological considerations.

\subsection{Rights of nature (including non-human persons)}

It may seem that calling on human rights in response to climate change merely replicates anthropocentric impulses, but it has long been recognized that human rights can ground justice claims consistent with non-anthropocentric values. ${ }^{120}$ Such claims often concentrate on conceptions of stewardship fundamental to indigenous cultural traditions. Reimagining the human subject of human rights could also yield a more

114. 42 U.S.C. $\$ 7607(d)(9)(A)$.

115. Massachusetts v EPA 549 US 497, 127 S.Ct. 1438, 167 L.Ed.2d. 248 (2007), 4.

116. Gray v Macquarie Generation [2010] NSWLEC 34; Gray v Macquarie Generation (No 3) [2011] NSWLEC 3.

117. Gray v Minister for Planning [2006] NSWLEC 720, 118-23.

118. Gray v Minister for Planning (2006) 152 LGERA 258, 125, 126, 135.

119. For a breakdown of treaties containing intergenerational equity, see J Hepburn 'Intergenerational Equity and Rights and International Criminal Law' in S Jodoin and M-C Cordonier Segger (eds), Sustainable Development, International Criminal Justice, and Treaty Implementation (Cambridge University Press, Cambridge 2013) 171-89.

120. K Bosselmann, 'Human Rights and the Environment: Redefining Fundamental Principles?', in B Gleeson and N Low (eds), Governing for the Environment: Global Problems, Ethics and Democracy (Palgrave Macmillan, Basingstoke 2001) 118-34; C Redgewell, 'Life, the Universe and Everything: A Critique of Anthropocentric Rights', in AE Boyle and MR Anderson (eds), Human Rights Approaches to Environmental Protection (Clarendon Press, Oxford, 1996) 71-88. 
all-embracing ethical dynamism and enable human rights to form part of a wider juridical responsiveness to the vulnerable materiality of the entire living order. Such an approach would reposition human beings as one category of rights-bearing subjects amongst others, including animals and Mother Earth. ${ }^{121}$ This now seems fundamental to the search for climate justice.

The identity of the dominant human subject folded into human rights has justifiably been criticized for its Eurocentricity and the abstract nature of legal subjectivity. ${ }^{122}$ Eurocentric subject-object assumptions ground international environmental law and climate law, as well as being foundational to Western hubristic mastery implicated in climate harms and environmental degradation. ${ }^{123}$ In turn, these flow from the Cartesian separation of humanity and nature at the core of Enlightenment rationality. Such assumptions present a central problem, with implications that we now briefly reflect upon.

Western law is predicated upon a series of virtually sacred binaries: human/nature; person/property; public/private; rational/irrational; reasonable/unreasonable, and just as fundamentally: human/animal; man/woman; culture/nature; white/non-white; property-owning/nomadic, human/non-human. On one side of these binaries there is always a privileged referent; on the other, a marginalized 'object' or identity that has historically been objectified. The privileged referent represents the characteristics projected onto the 'rational man', the privileged master-subject of the legal system. However, the advent of the Anthropocene (more accurately, the Capitalocene), ${ }^{124}$ along with fears about the terminal nature of the climate crisis, the growing political power of indigenous perspectives, the unsettling effects of new scientific insights, and the energies of a world-wide commons movement sensitive to the interaction between all living elements, mean that the binaries of Eurocentric thought are more clearly untenable than ever. ${ }^{125}$ The anthropocentrism of the universal 'human' at the heart of liberal conceptions of human rights is increasingly exposed as an attenuated, excluding figure. This points to the urgent need to think in more inclusive terms about a whole range of potentially rights-bearing subjects.

Unsurprisingly, law's anthropocentrism is increasingly challenged by those concerned to extend its ambit of concern to non-human living subjects. Arguments have been made for the legal standing of trees, ${ }^{126}$ the rights of animals such as

121. A Grear and LJ Kotzé, Research Handbook on Human Rights and the Environment (Edward Elgar Publishing, Cheltenham 2015).

122. R Kapur, 'Human Rights in the 21st Century: Take a Walk on the Dark Side' (2006) 28(4) Sydney Law Review 665; U Baxi, 'From Human Rights to the Right to be Human: Some Heresies' (1986) 13(3/4) India International Centre Quarterly 185; U Baxi, The Future of Human Rights (Oxford University Press, Oxford 2008); S Lecce, N McArthur and A Schafer (eds), Fragile Freedoms: The Global Struggle for Human Rights (Oxford University Press, Oxford 2017); C Douzinas, 'The Many Faces of Humanitarianism' (2007) 2(1) Parrhesia 28.

123. V Plumwood, Environmental Culture: The Ecological Crisis of Reason (Routledge, 2005); C Merchant, Radical Ecology: The Search for a Livable World (Routledge, Abingdon 2012).

124. See H Baer, 'Anthropocene or Capitalocene? Two Political Ecological Perspectives' (2017) 3(1) Human Ecology 1.

125. See L Kotzé, Environmental Law and Governance for the Anthropocene (Hart Publishing, Oxford 2017).

126. CD Stone, Should Trees Have Standing? Law, Morality and the Environment (Oxford University Press, Oxford 2010); A Grear (ed), Should Trees Have Standing? 40 Years On (Edward Elgar, Cheltenham 2012). 
great apes, ${ }^{127}$ and Mother Earth, ${ }^{128}$ to name just a few. ${ }^{129}$ There have been successful cases upholding the rights of nature in the face of human activities, perhaps the most famous being the Ecuadorian case on the right of the Vilcabamba River to its natural flow. ${ }^{130}$ Ecuadorian judges are increasingly applying the constitutional rights of Mother Earth in other cases to similar effect. ${ }^{131}$ Other legal systems are also granting legal personhood to natural features. In 2014, the Aotearoa New Zealand Parliament granted the former national park Te Urewera status as a legal entity with 'all the rights, powers, duties and liabilities of a legal person' ${ }^{132}$ Also in Aotearoa, the NZ Parliament recently awarded legal personality to the Whanganui River, as the entity Te Awa Tupua. ${ }^{133}$ Drawing directly on the Whanganui River example, a court in Uttarakhand in Northern India designated the Ganges and Yamuna Rivers as 'living entities having the status of a legal person' and possessing all corresponding rights. ${ }^{134}$ The same court then immediately extended this to glaciers, forests and many other natural entities. ${ }^{135}$

No longer can rights be directly linked to 'Reason' and its imbrication with 'biological determinism, racial and religious superiority, and civilizational maturity' ${ }^{136}$ Reason's long sway as the central structural legitimation for the constructed

127. For example, P Cavalieri, The Animal Question: Why Nonhuman Animals Deserve Human Rights (Oxford University Press, Oxford 2001); C Cohen and T Regan, The Animal Rights Debate (Rowman and Littlefield, London 2001); CR Sunstein and MC Nussbaum (eds), Animal Rights: Current Debates and New Directions (Oxford University Press, Oxford 2004).

128. World People's Conference on Climate Change and the Rights of Mother Earth, Cochabamba, Bolivia, April 22, 2010, Universal Declaration of Rights of Mother Earth.

129. See also Animal Welfare Board of India v A. Nagaraja (2014) 5 SCC 547 (India), extending the right to life in Article 21 of the Indian constitution to non-human animals.

130. See, eg, N Greene, 'The First Successful Case of the Rights of Nature Implementation in Ecuador', description and photos at <http://therightsofnature.org/first-ron-case-ecuador/> accessed 27 March 2017.

131. See, eg, CM Kauffman and PL Martin, 'Testing Ecuador's Rights of Nature: Why Some Lawsuits Succeed and Others Fail', Paper Presented at the International Studies Association Annual Convention Atlanta, GA, March 18, 2016; this paper identifies and analyses 13 cases where various constitutional legal tools were used to protect rights of nature in Ecuador.

132. Te Urewera Act, 27 July 2014, New Zealand Public Act, No 51; B Rousseau, 'In New Zealand, Lands and Rivers Can Be People (Legally Speaking)', The New York Times, 13 July 2016. For a discussion of this example, see CJ Iorns Magallanes, 'Maori Cultural Rights in Aotearoa New Zealand: Protecting the Cosmology that Protects the Environment' (2015) 21(2) Widener Law Review 273, 318-23 <http://ssrn.com/abstract=2677396> accessed 14 April 2017.

133. Te Awa Tupua (Whanganui River Claims Settlement) Act 2017 (2017, No. 7). For a discussion of this example, see CJ Iorns Magallanes, ibid, 313-18; see also CJ Iorns Magallanes, 'Reflecting on Cosmology and Environmental Protection: Maori Cultural Rights in Aotearoa New Zealand', in A Grear and LKotzé (eds), Research Handbook on Human Rights and the Environment (Edward Elgar, Cheltenham 2015).

134. See, eg, K McLaughlin, 'India Grants Sacred River Ganges and the Yamuna "Legal Person" Status in a Bid to Restore the Polluted Waterways to Health', Daily Mail (MailOnline), 21 March $2017<\mathrm{http} / / / \mathrm{www}$.dailymail.co.uk/news/article-4334454/India-grants-GangesYamuna-legal-person-status.html> accessed 12 April 2017.

135. Livelaw, 'Uttarakhand HC Declares Air, Glaciers, Forests, Springs, Waterfalls etc. as Legal Persons', Livelaw News Network, 1 April 2017) <http://www.livelaw.in/uttarakhandhc-declares-air-glaciers-forests-springs-waterfalls-etc-legal-persons/> accessed 14 April 2017.

136. R Kapur, 'The Citizen and the Migrant: Postcolonial Anxieties, Law, and the Politics of Exclusion/Inclusion' (2007) 8 Theoretical Inquiries in Law 537, 541. 
'inferiority' of the non-male, the non-white, the non-European and all others considered to be less than fully rational - which is fully reflected in patterns of climate injustice and climate racism - is crumbling, and its intrinsic anthropocentrism is coming under growing pressure. The appetite for expanding law's community of 'rights bearers' is growing.

Pre-Anthropocene subject-object relations between rational agents set against the environment as a mere backdrop are no longer plausible. Postmodern developments destabilize conceptions of 'the human' ${ }^{137}$ and law's dominant ways of ordering the world. What is at stake is "nothing less than a challenge to some of the most basic assumptions that have underpinned the modern world, including its normative sense of the human and its beliefs about human agency, [and] ... its material practices such as the ways we labor on, exploit and interact with nature'. ${ }^{138}$ It is no longer plausible to embrace fundamental assumptions that shore up the 'the conventional sense that agents are exclusively humans who possess cognitive abilities, intentionality and freedom to make autonomous decisions and the corollary presumption that humans have the right or ability to master nature'. ${ }^{139}$ Instead, the central task is to reimagine the 'situation of the human in a more-than-human world'. ${ }^{140}$

Extending rights to animals and nature rightly undermines the anthropocentrism of law and potentially enables human rights to contribute to the construction of a 'more-than-human' world. Several contemporary philosophical theories make a strong case for the direct and independent rights of 'non-human' entities. Martha Nussbaum, for example, argues for the rights of sentient animals using the capabilities approach, citing the rights to life, bodily health, bodily integrity, senses, imagination and thought, emotion, practical reason, affiliation, play and control over one's own environment. ${ }^{141}$ Robert Garner argues that a complete theory of justice must include the rights of animals. ${ }^{142}$

It is equally important to develop a compelling legal account of responsibility for protecting such rights bearers and their interests. Christopher Stone is a key proponent of the rights of the environment but does not develop an adequate account of responsibility for protecting those rights. ${ }^{143}$ This question requires full and nuanced attention if non-human rights are to be adequately operationalized and human agency resituated within a more-than-human world. What agency now means, where and how it operates with what aims, who has it and how it is to be understood are questions of fresh

137. D Chakrabarty, 'The Climate of History: Four Theses' (2009) 35(2) Critical Inquiry 197; J Davies, The Birth of the Anthropocene (University of California Press, Oakland, CA 2016); $\mathrm{C}$ Hamilton, F Gemenne and $\mathrm{C}$ Bonneuil, The Anthropocene and the Global Environmental Crisis: Rethinking Modernity in a New Epoch (Routledge, Abingdon 2015).

138. D Coole and S Frost, New Materialisms: Ontology, Agency and Politics (Duke University Press 2010, Durham NC) 137.

139. Ibid 250.

140. A Neimanis, 'Alongside the Right to Water, a Posthumanist Feminist Imaginary' (2014)

5(1) Journal of Human Rights and the Environment 5, 14.

141. MC Nussbaum, Frontiers of Justice: Disability, Nationality, Species Membership (Harvard University Press, Cambridge MA 2007).

142. R Garner, A Theory of Justice for Animals: Animal Rights in a Nonideal World (Oxford University Press, Oxford 2013).

143. Stone, above (n 126). For a fuller discussion of such an account of responsibility, see CJ Iorns Magellanes, 'Seeing Responsibility for Nature Through a Rights Lens', in L Te Aho, M Humphries and B Martin (eds), Law for Responsibility for Climate and Freshwater (Greenleaf, Abingdon 2017, forthcoming). 
and urgent significance given the complexities of post-human developments and new materialist insights in the Anthropocene.

There are profound reasons to doubt that historically privileged human centrality is now sustainable in any meaningful sense. Anthropocentrism, and the patterns of intraand inter-species injustice it produces, is an inadequate legal and philosophical response to the scale and urgency of climate change. In response to this problem, the Declaration on Human Rights and Climate Change departs from existing human rights documents in adopting an ontological foundation suspicious of (Western) anthropocentrism. The Declaration attempts to tread a careful path between directly protecting the more-than-human, redefining the human in a more-thanhuman situation, and protecting the rights of such re-imagined human beings. The Declaration also reflects the need (implicit throughout this article) for ongoing hermeneutical suspicion concerning patterns of intra-species injustice while expanding the frame of normative attention towards bodies of all kinds caught up in inter-species injustice and the crisis of climate change.

In short, the Declaration reflects the vital importance of reimagining the 'human', 'human rights' and human responsibilities in response to twenty-first century complexities, especially but not least climate change. The Declaration accordingly seeks to situate the human in a network of species and systems while simultaneously recognizing the independent ethical significance and fundamental interests of otherthan-human creatures and the living systems upon which all life on Earth depends. The Declaration embodies the conviction that humans should be reconceived as intrinsically dependent upon natural systems and processes in which we are embedded. It reflects a more responsibility-centred ethic of stewardship responsive to indigenous ontologies and to the positions of faith communities, to which we now turn.

\subsection{The stewardship and responsibility framework}

Some contributors to the drafting process emphasized the importance of faith communities in crafting a response to climate change. Their contributions reflect an alternative way of valuing nature, other-than-human creatures, and living systems based upon human responsibility - a position sometimes described as 'weak' anthropocentrism. Such a position might be closer to what may be called 'anthropo-deontology', ${ }^{144}$ but whatever the label ultimately chosen - humanity is made responsible by a concept of human stewardship and accountability.

The idea of human stewardship and responsibility for non-human living beings and entities is not new; it is deeply embedded in many religious and philosophical traditions. This is true even of religious ethics commonly regarded as Western, and even ethics that remain resolutely anthropocentric. In his classical, if controversial, discussion of the Judeo-Christian tradition, John Passmore argues that Genesis can be interpreted as a mandate for human beings to take responsibility for the rest of the natural world. Passmore presents a strong argument for changes in attitudes towards the

144. The term 'anthropo-deontology' drives at the inescapability (both ethical and practical) of human responsibility but does so in a way theoretically compatible with the de-centering of relentless human priority required by indigenous and new materialist approaches to 'nature'. 'Weak' anthropocentrism, on the other hand, remains anthropocentric and is linguistically closer to the notion of human centrality. 
environment that lead to the acceptance of responsibility for exploiting the biosphere. ${ }^{145}$ Pope Francis, in his climate-change-focused encyclical, Laudato Si: On Care for our Common Home, wrote in a more overtly anthropocentric vein that 'Once we start to think about the kind of world we are leaving to future generations, we look at things differently; we realize that the world is a gift which we have freely received and must share with others' ${ }^{146}$ Seyyed Hossein Nasr argues that the Koran and the hadith contain references to the need to protect nature. Citing the Koran, Nasr argues that Allah chooses man (sic) as his khalifa, meaning 'vice-regent', making him the guardian of God's creation. ${ }^{147}$ Each of these alternative ways of presenting anthropocentrism places a strong focus upon the notion of human responsibility for the world as biosphere, as shared space, and as nature. Indigenous cosmologies and cultures go even further - in some cases, towards ontologies in which human beings are no longer centrally important, even as responsible agents.

While responsibility can be viewed as the obverse of rights and thus as intrinsic to all rights frameworks, responsibility is regularly neglected. Emphasizing responsibility shows that we are not simply 'adding rights of nature to the catalogue of the rights of humans'. ${ }^{148}$ Focusing on responsibility enables the move towards a new relationship with nature, which is essential if the anthropocentric destruction of the foundation of life is to be halted. ${ }^{149}$

Indigenous cosmologies consider humans to be part of nature and co-dependent with it. Indigenous creation and other stories typically tell how people today are descended from, and genealogically related to, the natural world and dependent on it. ${ }^{150}$ Indigenous practices recognize and codify the concept of stewardship and responsibility towards nature through ritual and material practice. ${ }^{151}$ Indigenous customary law reflects cosmologies in which humans are just one interwoven partner among many in a living world. For example, Melanesian customary law incorporates traditional indigenous knowledge, and cultural and religious beliefs - traditional Melanesian customs

145. J Passmore, Man's Responsibility for Nature: Ecological Problems and Western Traditions (Scribner, New York 1974).

146. Pope Francis, the encyclical letter, Laudato Si: On Care for Our Common Home (The Vatican 2015).

147. S Hossein Nasr, The Encounter of Man and Nature: The Spiritual Crisis of Modern Man (Unwin Paperbacks, London 1968).

148. K Bosselmann, 'Environmental and Human Rights in Ethical Context', in A Grear and L Kotze (eds), Research Handbook on Human Rights and the Environment (Edward Elgar, Cheltenham 2015), 531.

149. For further discussion of a legal framework based on rights for nature and responsibility over it, see CJ Iorns Magallanes and L Sheehan, 'Reframing Rights and Responsibilities to Prioritize Nature', in M Scanlan (ed), Law and Policy for a New Economy (Edward Elgar, Cheltenham 2017, forthcoming).

150. For an illustration of the North American context, see R Erdoes and A Ortiz, American Indian Myths and Legends (Pantheon Books, New York 1984). This book contains 166 such stories, covering Creation, the sun, moon and stars, heroes, warriors, love, the Trickster, 'Animals and Other People', ghosts and the spirit world, and 'Visions of the End'. For further discussion including how law has been unable to recognize First Nations' cosmologies, see, eg, CJ Iorns Magallanes, 'Native American Values and Laws of Exclusion', in K Hirokawa (ed), Environmental Law and Contrasting Ideas of Nature: A Constructivist Approach (Cambridge University Press, Cambridge 2014).

151. G Follett, 'Defining the Formless: Customary Law in the Pacific' (2014) 39(2) Alternative Law Journal 125, 126; E Techera, 'Enhancing Legal Frameworks for Biodiversity Conservation in the Pacific' (2015) Pacific Conservation Biology 1, 2. 
integrated into the daily lives of most citizens, holistically govern environmental protection, attitudes, values, family and community structures, behaviour and participation. ${ }^{152}$ Similarly, much of the traditional knowledge held by fishing communities in Vanuatu relates to 'increasing catches while managing resources of cultural, social and subsistence value', ${ }^{153}$ and traditional 'beliefs and practices associated with fisheries and their management follow natural cycles of resource abundance, accessibility, and respect for customary rules enshrined in oral traditions' ${ }^{154}$

Amongst the most prominent examples of indigenous epistemologies are Andean cosmovisions based upon the concept of buen vivir (living well). They reject the fetishization of economic growth in favour of a model of development based on harmony and solidarity in contrast to the possessive individualism of Eurocentric thinking and neoliberal capitalism. ${ }^{155}$ In buen vivir, human well-being is contingent upon communal life in harmony with nature, and consistent with principles of reciprocity, complementarity and relationality. There is no definitive idea of buen vivir, but the conception has certain core elements. It does not accept the separation between nature and society that characterizes Eurocentric thinking; instead it offers a biocentric conception in which nature is conceptualized as Pachamama (Mother Earth), the source of all life, of which humans are but one part. Nature is an essential and constitutive element of social life, and valued for itself rather than as natural capital.

These values are reflected in the People's Agreement of Cochabamba, which states that:

In an interdependent system in which human beings are only one component, it is not possible to recognize rights only to the human part without provoking an imbalance in the system as a whole. To guarantee human rights and to restore harmony with nature, it is necessary to effectively recognize and apply the rights of Mother Earth. ${ }^{156}$

Mother Earth has the right to live and to exist, to be respected, and to regenerate its bio-capacity and continue its vital cycles and processes free of human alteration.

Human rights and the rights of Pachamama are complementary. All living organisms have the "right to maintain their identity and integrity as differentiated beings, selfregulated and interrelated' and 'to be free of contamination and pollution, free of toxic and radioactive waste'. ${ }^{157}$ The People's Agreement calls 'upon States to recognize, respect and guarantee the effective implementation of international human rights standards and the rights of indigenous peoples', including 'full and effective implementation of the right to consultation, participation and prior, free and informed consent of indigenous peoples in all negotiation processes, and in the design and implementation

152. G Romulus and PHC Lucas, 'Landscape Stewardship: New Directions in Conservation of Nature and Culture, the Caribbean to the Pacific: Community Conservation in Small Island States' (2000) 17(1) The George Wright Forum 47.

153. F Hickey, 'Traditional Marine Resource Management in Vanuatu: Acknowledging, Supporting and Strengthening Indigenous Management Systems' (2006) 20 SPC Traditional Marine Resource Management and Knowledge Information Bulletin 1.

154. Ibid.

155. E Gudynas, 'Buen Vivir: Today's Tomorrow' (2011) 54(4) Development 441; U Villalba, 'Buen Vivir vs Development: A Paradigm Shift in the Andes?' (2013) 34(8) Third World Quarterly 1427.

156. People's Agreement of Cochabamba, April 24, 2010 adopted at the World People's Conference on Climate Change and the Rights of Mother Earth.

157. Ibid. 
of measures related to climate change'. ${ }^{158}$ It demands protection for individuals and communities displaced by climate change.

The Ecuadorian Constitution grants rights to Pachamama and buen vivir is a guiding ethical principle of Bolivia's constitution. ${ }^{159}$ Buen vivir is posited not as an alternative form of development, but rather an alternative to carbon-based, extractivist development. The implementation of the rights of nature has inevitably been contradictory, but they point to the possibilities inherent in alternative epistemologies that seek to overcome the problems of Eurocentric rationality and models of development that fetishize quantity (endless economic growth) over quality (of the well-being of the Earth and its biota as well as human beings).

The value of customary law and traditional indigenous knowledges should not be underestimated as the planet grapples with the impacts of climate change on human rights, particularly in the formulation of local responses. The plurality of situated indigenous knowledges is a rich source of guidance, and "climate governance dialogue should be supported starting at grassroots where indigenous people, with their banks of traditional knowledge, should characterise the policy discourse for sustainability'. 160

\subsection{Responsible actors: individuals, businesses and states}

Responsibilities to mitigate as well as adapt to climate change in ways that respect justice and human rights fall on all persons, businesses and states, individually and collectively.

A human rights approach must insist, moreover, that states' obligations cannot be limited to what happens within their borders but extend extra-territorially. ${ }^{161}$ It must also recognize that states have a duty to protect against human rights abuses no matter who they are committed by. Further, a human rights approach must incorporate duties of international cooperation and assistance designed to achieve the full realization of human rights. ${ }^{162}$ These requirements are essential in order to deal with the transboundary nature of climate change. There is a clear correlation between the universality of human rights and the global nature of climate change. International cooperation is essential if we are to have any meaningful hope of dealing with climate-related harms. Since many countries lack sufficient resources for mitigation or adaptation, cooperation is a precondition for the protection of the rights and duties

158. Ibid.

159. The Ecuadorian Constitution guarantees the rights of buen vivir (articles 12-34) and grants rights to nature (articles 71-4). Constitución Política de la República del Ecuador, 20 October 2008. In Bolivia, buen vivir informs the 2009 Constitution, which does not grant rights to nature. However, Pachamama is protected under the Law of the Rights of Mother Earth (Law 071 of the Plurinational State) passed by the Plurinational Legislative Assembly on 21 December 2010.

160. N Chanza and A De Wit, 'Enhancing Climate Governance Through Indigenous Knowledge: Case in Sustainability Science' (2016) 112(3) South African Journal of Science 1.

161. See for example the Maastricht Principles on Extraterritorial Obligations of States in the Area of Economic, Social and Cultural Rights (2011), available at <http://www.etoconsortium. org/nc/en/main-navigation/library/maastricht-principles/?tx_drblob_pi1\%5BdownloadUid\% $5 \mathrm{D}=23>$.

162. See, eg, Article 2(1) of the International Covenant on Economic, Social and Cultural Rights. 
in the Declaration. ${ }^{163}$ States are primarily responsible for establishing effective remedies and redress for climate harms. This is particularly relevant for those displaced by climate change. Those forced to cross international borders are currently unprotected under international refugee or human rights law - a legal lacuna that needs to be filled. ${ }^{164}$

The inclusion of businesses in the Declaration recognizes the large part they have played in the emission of greenhouse gases and the fact that they are necessarily implicated in solutions to anthropogenic warming. Non-state actors, and businesses in particular, have played a significant role in the genesis of the climate crisis through the extraction, sale and use of fossil fuels, and by exerting pressure on states to permit their continued extraction, sale and use for profit. ${ }^{165}$ It has been calculated that just 90 companies have caused two-thirds of greenhouse gas emissions since the dawn of industrialization. ${ }^{166}$ 'Half of the estimated emissions were produced just in the past 25 years - well past the date when governments and corporations became aware that rising greenhouse gas emissions from the burning of coal and oil were causing dangerous climate change'. ${ }^{167}$ It is thus essential to insist that businesses have a duty to protect the climate and to respect the rights set out in the Declaration.

\subsection{The range of rights and responsibilities}

Procedural rights, rights to an effective remedy and substantive rights all have a role to play in the search for climate justice. ${ }^{168}$

A wide range of procedural rights is essential. ${ }^{169}$ People must have relevant information about - and the ability to participate in - decisions on mitigation and

163. The UN Human Rights Council has made several calls for enhanced cooperation and assistance, noting that 'the global nature of climate change calls for the widest possible cooperation by all countries and their participation in an effective and appropriate international response'. Resolution 29/15 of the Human Rights Council, 30 June 2015, A/HRC/29/L.2. Similar resolutions were adopted in 2014 and 2016 (Resolution 26/27 of the Human Rights Council, 5 July 2014, and Resolution 32/33, 18 July 2016).

164. This need is recognized in paragraph 51 of the Paris Decision, which calls for the development of recommendations on measures 'to avert, minimise and address displacement related to the adverse effects of climate change' by a task force established under the Warsaw International Mechanism on Loss and Damage. UNFCCC, Adoption of the Paris Agreement, 12 December 2015, FCC/CP/2015/L.9.

165. In relation to exerting pressure on states, see, eg, N Oreskes and E Conway, Merchants of Doubt: How a Handful of Scientists Obscured the Truth on Issues from Tobacco Smoke to Global Warming (Bloomsbury Press, New York 2010).

166. R Heede, 'Tracing Anthropogenic Carbon Dioxide and Methane Emissions to Fossil Fuel and Cement Producers, 1854-2010' (2014) 122 Climatic Change 229.

167. S Goldenberg, 'Just 90 Companies Caused Two-thirds of Man-made Global Warming Emissions', The Guardian, 20 November $2013<$ <ttps://www.theguardian.com/environment/ 2013/nov/20/90-companies-man-made-global-warming-emissions-climate-change > accessed 12 April 2017.

168. See, eg, the reports of the United Nations Special Rapporteur on Human Rights and Environment, available at UN OHCHR, and the Mary Robinson Foundation - Climate Justice, Principles of Climate Justice.

169. See, eg, OHCHR, Mapping Human Rights Obligations Relating to the Enjoyment of a Safe, Clean, Healthy and Sustainable Environment, June 2014; A/HRC/31/5, paras 50-64. 
adaptation. This is recognized under the $\mathrm{UNFCCC}^{170}$ as well as the Paris Agreement, ${ }^{171}$ but procedural rights and duties need to be further developed. The United Nations Special Rapporteur on Human Rights and the Environment, John Knox, argues that procedural justice requires information on climate change risks and effects, GHG assessments, and detailed options for mitigation and adaptation. ${ }^{172}$ Education and the proper provision of information facilitate public participation in decisions on mitigation and adaptation projects, upon which states should conduct adequate and meaningful consultation with those affected. Special attention must be given to facilitating the participation of marginalized and disadvantaged groups. Indigenous rights to collective self-determination and to free, prior and informed consent, along with respect for indigenous knowledges and processes are relevant to indigenous participation as well as to the achievement of procedural justice. Protecting the closely related rights to freedom of expression and association is also important, especially for environmental activists, who are increasingly victims of harassment and physical violence. ${ }^{173}$

Effective remedies are required to protect communities suffering from climate harms. Knox argues that those who suffer human rights violations are entitled to access effective remedies, including for human rights violations related to climate change. ${ }^{174}$ Remedies for loss and damage caused by climate change, including compensation, are being demanded by developing countries, ${ }^{175}$ and proper redress will require appropriate administrative, legislative and judicial measures at national and international levels.

Perhaps the most fundamental substantive right required is to a healthy and ecologically sound environment. Such a right exists in various forms in an increasing number of jurisdictions and instruments. ${ }^{176}$ It is arguably a precondition for all other rights, including the rights to life, food and water. Although such a right has not yet been formally recognized in international law, it is increasingly urgent that it should be. There is a clear need to establish protection of the life-supporting capacity of Earth as a human right - and to give rights to nature and to Mother Earth.

170. Article 6: parties commit to promote and facilitate 'public participation in addressing climate change and its effects in developing adequate responses', as well as public access to information on climate change.

171. Article 12: to enhance public participation and access to information.

172. See, eg, Report of the Special Rapporteur on the issue of human rights obligations relating to the enjoyment of a safe, clean, healthy and sustainable environment, 11 February 2016, $\mathrm{A} / \mathrm{HRC} / 31 / 52$, para 54.

173. See, eg, Global Witness, 'How Many More?' (Report, 2015) <https://www.globalwitness. org/en/campaigns/environmental-activists/how-many-more/> accessed 13 April 2017; Global Witness, 'Deadly Environment' (Report 2014) <https:/www.globalwitness.org/en/campaigns/ environmental-activists/deadly-environment/> accessed 13 April 2017. At least three wellknown activists were assassinated in 2016; Dan Moshenberg, 'Berta Cáceres, Nelson Garcia, Sikhosiphi Bazooka Rhadebe: We Must Take Action!' Women in and Beyond the Global (23 March 2016) <http://www.womeninandbeyond.org/?p=19909> accessed 13 April 2017.

174. Report of the Special Rapporteur on the issue of human rights obligations relating to the enjoyment of a safe, clean, healthy and sustainable environment, 11 February 2016, A/HRC/31/ 52 , para 62.

175. Ibid para 64.

176. See, eg, Organisation of American States, Climate Change: A Comparative Overview of the Rights-based Approach in the Americas (Department of Sustainable Development of the General Secretariat of the Organisation of American States, 2016). 


\subsection{Emergent instruments and momentum}

The Paris Agreement was adopted at COP 21 in December 2015 and came into force on 4 November $2016 .{ }^{177}$ Prior to and throughout the negotiations, many states and nonstate actors vigorously advocated the inclusion of human rights. ${ }^{178}$ To cite but one example, the Inter-American Commission on Human Rights expressed its concern regarding the grave harm climate change poses to the universal enjoyment of human rights and urged member states of the Organization of American States to ensure that the agreement reached incorporated human rights in a holistic manner. ${ }^{179}$ Despite the pressure for a prominent role for them in the Agreement, human rights were excised from the final draft. ${ }^{180}$ This final result seems incongruous given the clear global groundswell of recognition concerning the impacts of climate change on fundamental human rights. Before the conference a suite of human rights and climate change instruments emerged, including the St Julian's Declaration on Climate Justice, issued by the Commonwealth Forum of National Human Rights Institutions; ${ }^{181}$ the French Declaration of Humankind's Rights commissioned by President Hollande; ${ }^{182}$ the Oslo Principles on Global Climate Change Obligations; ${ }^{183}$ the Global Network for the Study of Human Rights and the Environment's (GNHRE) Draft Declaration on Human Rights and Climate Change; ${ }^{184}$ and, most recently, the GNHRE's Declaration on Human Rights and Climate Change, ${ }^{185}$ the subject of this article.

177. Conference of the Parties, United Nations Framework Convention on Climate Change, Report of the Conference of the Parties on its Twenty First session, held in Paris from 30 November to 13 December 2015 - Addendum - Part 2: Action taken by the Conference of the Parties at its Twenty First Session, UN Doc FCCC/CP/2015/10/Add.1 (29 January 2016), Decision 1/CP.21 'Adoption of the Paris Agreement'.

178. For a discussion of the placement of human rights in the various drafts, see, eg, Catherine Iorns Magallanes, 'Human Rights in the Draft Climate Change Agreement' (10 December 2015) $<$ http://paristext2015.com/2015/12/human-rights-in-the-draft-climate-change-agreement/> accessed 25 April 2017.

179. Inter-American Commission on Human Rights, 'IACHR Expresses Concern Regarding Effects of Climate Change on Human Rights' (Press Release 140/15 2015) <http://www.oas. org/en/iachr/media_center/PReleases/2015/140.asp> accessed 15 April 2017.

180. 'Climate Talks: Anger Over Removal of Human Rights Reference from Final Draft', The Guardian, 11 December $2015<\mathrm{https}: / /$ www.theguardian.com/global-development/2015/dec/11/ paris-climate-talks-anger-removal-reference-human-rights-from-final-draft>; Renee Lewis, 'Draft of Paris Climate Deal Omits References to Human Rights', Aljazeera, 11 December $2015<$ http://america.aljazeera.com/articles/2015/12/11/cop21-draft-leaves-out-indigenousrights.html>; Benoit Mayer, 'Human Rights in the Paris Agreement' (2016) 6(1-2) Climate Law 109-17.

181. Commonwealth Forum of National Human Rights Institutions, 'St. Julian's Declaration on Climate Justice', Plenary Assembly of the Biennial Meeting in Malta (25 November 2015). 182. Droits de l'Humanité, 'Universal Declaration of the Rights of Humankind' (Declaration, 2015) <http://droitshumanite.fr/DU/the-declaration-in/> accessed 14 April 2017.

183. Expert Group on Global Climate Obligations, 'Oslo Principles on Global Climate Change Obligations' (Symposium at the Kings College in London 2015) <http://globaljustice.macmillan. yale.edu/sites/default/files/files/OsloPrinciples.pdf> accessed 15 April 2017.

184. Global Network for the Study of Human Rights and the Environment, 'Draft Declaration on Human Rights and Climate Change' (Draft Declaration) <http://gnhre.org/gnhre-draftdeclaration/draft-declaration-on-human-rights-and-climate-change-2/> accessed 15 April 2017. 185. Global Network for the Study of Human Rights and the Environment, 'Declaration on Human Rights and Climate Change' (Declaration, 2016) <http://gnhre.org/declarationhuman-rights-climate-change/> accessed 15 April 2017. 
In addition to such instruments, in 2015 human-rights-based legal actions in relation to climate change also gained prominence worldwide. The first and most notable such decision is the Urgenda case in June 2015, in which a Dutch court ruled that the Netherlands owes a duty of care to its citizens on the basis of fairness towards future generations, and is thus obliged to increase its efforts to reduce its greenhouse gas emissions. ${ }^{186}$

Another prominent decision is that in Asghar Leghari in Pakistan, decided in September 2015. ${ }^{187}$ The High Court of Lahore held that despite policy initiatives to combat climate change, including the National Climate Change Policy, 2012 and the Framework for Implementation of Climate Change Policy (2014-2030), there had been a profound level of 'inaction, delay and lack of seriousness on the part of the Federal Government and the Government of the Punjab to address the challenges and to meet the vulnerabilities associated with Climate Change'. ${ }^{188}$ Moreover, 'delay and lethargy of the State in implementing the Framework offends the fundamental rights of the citizens which need to be safeguarded'. ${ }^{189}$ The court asserted its jurisdiction on the basis of:

Fundamental rights, like the right to life (article 9) which includes the right to a healthy and clean environment and right to human dignity (article 14) read with constitutional principles of democracy, equality, social, economic and political justice include within their ambit and commitment, the international environmental principles of sustainable development, precautionary principle, environmental impact assessment, inter and intra-generational equity and public trust doctrine. ${ }^{190}$

Another prominent series of cases is the Our Children's Trust litigation in the United States, in which young people filed suit, alleging violation of their human and constitutional rights, including to life and liberty, as a result of the federal government's promotion of the development and use of fossil fuels. ${ }^{191}$ The Oregon Federal District Court case of Juliana et al., filed in August 2015 is currently the most well known, as it has been allowed to proceed on the basis that: ${ }^{192}$

This action is of a different order than the typical environmental case. It alleges that defendants' actions and inactions - whether or not they violate any specific statutory duty - have so profoundly damaged our home planet that they threaten plaintiffs' fundamental constitutional rights to life and liberty. ${ }^{193}$

186. Urgenda Foundation $v$ The State of the Netherlands (Ministry of Infrastructure and the Environment) (2015) HA ZA 13-1396, 30. For more information, see, eg, the website of the NGO Urgenda <http://www.urgenda.nl/en/climate-case/>, including an English translation of the case. See also R Cox, 'The Liability of European States for Climate Change' (2014) 78 Utrecht Journal of International and European Law 3; R Cox, 'A Climate Change Litigation Precedent: Urgenda Foundation v The State of the Netherlands' (2015) 79 Centre for International Governance Innovation 1. Note that the Dutch government lodged an appeal in September 2015. 187. Asghar Leghari v Federation of Pakistan WP 25501/2015.

188. Ibid 1.

189. Ibid 8.

190. Ibid 7.

191. For information on the range of cases supported by Our Children's Trust see eg <https:// www.ourchildrenstrust.org/>.

192. Kelsey Cascadia Rose Juliana et al. v United States of America et al., Case No. 6:15-cv01517-TC (United States Federal District Court, District of Oregon, Eugene Division; Judge Ann Aiken, November 10, 2016).

193. Ibid 52. 
The judge stated that she had 'no doubt that the right to a climate system capable of sustaining human life is fundamental to a free and ordered society' ${ }^{194}$ and cited Minors Oposa ${ }^{195}$ to the effect that the right of future generations to a 'balanced and healthful ecology' is so basic that it 'need not even be written in the Constitution for [it is] assumed to exist from the inception of humankind'. ${ }^{196}$

During COP 21, the Philippines Commission on Human Rights announced an investigation into 50 Carbon Majors including Chevron, ExxonMobil, BP, Royal Dutch Shell and ConocoPhillips for allegedly violating the rights of Filipinos. ${ }^{197}$ These companies are amongst the 90 corporations responsible for the majority of global $\mathrm{CO}_{2}$ and methane emissions in the earth's atmosphere. ${ }^{198}$ This is the world's first national human rights investigation that might hold fossil fuel companies responsible for the impacts of climate change.

Since COP 21, human rights and climate change cases continue to be lodged in developing and developed nations alike, ${ }^{199}$ providing evidence of a groundswell of litigation in which human rights are a central aspect. It is against this background of escalating litigation, evolving doctrinal and theoretical developments and growing pressure for the protection of human rights from climate justice coalitions that the drafting of the Declaration on Human Rights and Climate Change should be positioned.

\section{CONCLUSION}

As we noted above, there are signs of a turning juridical tide motivated by a deeper understanding of the implications of the impacts of climate change on human rights. The Declaration on Human Rights and Climate Change has been developed as a normative tool to support the aspirations of those who want to build alternative climate futures. As we have demonstrated, climate change is emphatically more than a technical or scientific problem. It represents a profound crisis of human hierarchies, fraught with uneven distributions of vulnerability. It is therefore unsurprising that so many recent initiatives point in the direction of seeing human rights as intrinsically threatened by climate change. Indeed, it is vital that respect for human rights should now be understood as an indispensable element of any adequate approach to climate change. Human rights offer a powerful meta-ethical language of critique and the seeds of alternative future histories, but only - we suggest - where those rights are understood to refer to a re-imagined humanity. The Declaration recognizes, emphatically,

194. Ibid 32.

195. Oposa v Factoran, 33 I.L.M., 87, see above (nn 100-4) and accompanying text.

196. Juliana et al., above (n 192), 50.

197. The Philippines, Petition Requesting for Investigation of the Responsibility of the Carbon Majors for Human Rights Violations or Threats of Violations Resulting from the Impacts of Climate Change, 12 May 2015. This investigation was petitioned for by Greenpeace Southeast Asia, together with 13 Filipino civil society organizations and 18 individuals. It is also supported by a number of other experts, activists and organizations, including Amnesty International.

198. Ibid.

199. The Columbia Law School Sabin Centre for Climate Change Law tracks climate change litigation cases around the world; see $<\mathrm{http}: / /$ columbiaclimatelaw.com/ $>$. For a direct link to the charts containing the cases, see $<w w w . c l i m a t e c a s e c h a r t . c o m>$. 
that humanity is irrevocably entangled with multiple non-human others, and radically dependent upon a healthy biosphere and a healthy planetary climate-life.

The Declaration understands climate change through coupled human and nature systems, the doctrine of inter- and intra-generational equity and the urgent need to develop human rights and responsibilities towards the more-than-human world, and towards Earth, our shared home and the planetary entanglement of life in all its variety. The Declaration recognizes the inequitable impacts of climate change on vulnerable people, such as children, women, indigenous peoples and people in less developed countries. The Declaration overtly acknowledges the stewardship role of human beings in the protection of the rights of nature and therefore calls for an enhanced duty of care placed upon the current generation.

The Declaration on Human Rights and Climate Change, we argue, is an important attempt to articulate a growing sensibility critical of consumer and industrial excesses, and critical of anthropocentric privilege and the destructive human hierarchies implicated in the climate crisis. The Declaration issues an important call to respond to the urgent need for climate change to be addressed as the differential imposition of injustice upon humans, non-human living beings and systems, and the Earth-system itself, by recognizing, in short, in its own words that 'the ultimate realization of human rights in the age of climate crisis requires the full legal protection of the living beings and systems upon which human life depends'. 


\section{DECLARATION ON HUMAN RIGHTS AND CLIMATE CHANGE ${ }^{200}$}

\section{Preamble}

Guided by the United Nations Charter; The Universal Declaration of Human Rights; The International Covenant on Economic, Social and Cultural Rights; The International Covenant on Civil and Political Rights; The United Nations Declaration on the Rights of Indigenous Peoples; The Convention on the Elimination of All Forms of Discrimination against Women; The Vienna Declaration and Program of Action of the World Conference of Human Rights; The Convention on the Rights of the Child; The Draft United Nations Declaration on the Rights of Peasants; The International Labour Organization Convention No. 169; The 2030 Sustainable Development Goals; The Universal Declaration of the Rights of Mother Earth; The Earth Charter; The Nagoya Protocol; Title II of the 2008 Constitution of Ecuador, and other relevant international rights instruments,

Guided by The Stockholm Declaration of the United Nations Conference on the Human Environment; The United Nations Framework Convention on Climate Change, its Kyoto Protocol and the Paris Agreement; The World Charter for Nature; The United Nations Convention on the Law of the Sea; The Rio Declaration on Environment and Development, and other relevant instruments of international environmental law,

Reaffirming the universality, indivisibility, interdependence and interrelationality of all human rights, the interrelationality of all life on Earth and the dependency of all life on Earth on a healthy biosphere and Earth system integrity,

Recognizing that climate change, caused by the human industrial and consumer activities, disproportionally affects indigenous peoples, the poor, women and children, the vulnerable, small island and low elevation coastal communities, developing countries, least developed countries, future generations and innumerable living beings and systems,

Recognizing that the ultimate realization of human rights in the age of climate crisis requires the full legal protection of the living beings and systems upon which human life depends,

Recognizing that human beings are part of the living Earth system,

Recognizing the climate destructive and ecocidal results of assuming human separation from nature,

Recognizing the need for all cultures, faiths and traditions to play a role in the fullest development of climate and environmental stewardship, the teaching of respect for all living beings and systems and the development of climate resilient communities,

Recognizing that science confirms the threats of climate change to the Earth's systems and its multiple life forms,

Recognizing that science confirms the threat of climate change to the livelihoods and well-being of present and future generations,

200. The Global Network for the Study of Human Rights and the Environment, Declaration on Human Rights and Climate Change <http://gnhre.org/declaration-human-rights-climate-change/>. 
Recognizing that climate impacts disproportionally affect innumerable living beings and systems that are intrinsically valuable in their own right and unable to defend themselves,

Recognizing that climate change displaces populations and that international, crossborder and internal migration has increased due to climate change and is likely to continue to do so,

Recognizing that courts and jurists of international standing link the fulfillment of human rights to a secure, healthy and ecologically viable environment, and consequently recognize that harming the environment undermines human rights

Recognizing that it is the stewardship responsibility of human beings to respond to the climate harms and damage caused by human activities,

Deeply concerned by the severe human rights consequences of the continuing political failure to reach adequate commitments on climate mitigation and adaptation; by the dominance of the market as the primary value coordinating international responses to the climate crisis; and by the ongoing lack of accountability for corporate actors that violate human, environmental and climate rights,

Convinced that the potential irreversibility of climate change effects gives rise to an urgent need for new forms of state and non-state responsibility, accountability and liability.

\section{THE FOLLOWING PRINCIPLES ARE DECLARED:}

I:

1. Human rights and a profound commitment to climate justice are interdependent and indivisible.

2. All human beings, animals and living systems have the right to a secure, healthy and ecologically sound Earth system.

3. All human beings have the right to fairness, equity and justice in all climate resilience, adaptation and mitigation measures and efforts.

4. All human beings have the right to a planetary climate suitable to meet equitably the ecologically responsible needs of present generations without impairing the rights of future generations to meet equitably their ecologically responsible needs.

5. All human beings, animals and living systems have the right to the highest attainable standard of health, free from environmental pollution, degradation and harmful emissions and to be free from dangerous anthropogenic interference with the climate system such that rising global temperatures are kept well below 2 degrees centigrade above preindustrial levels.

6. All human beings have the right to investments in adaptation and mitigation to prevent the deleterious consequences of anthropogenic climate change, and to international solidarity and timely assistance in the event of climate change driven catastrophes.

7. All human beings, animals and living systems have the right to fairness, equity and justice in respect of responses to the threat of climate change. This includes protection from deleterious impacts caused by adaptation and 
mitigation efforts to develop climate resilience, and by the potential deployment of climate geoengineering technologies.

8. All human beings have the right to a just transition towards a sustainable society characterized by meaningful inclusion and distributive justice.

II:

9. All human beings have the right to information about, and to participation in, decision-making processes related to alterations made to the physical environments they rely upon for their health and survival.

10. All human beings have the right to information concerning the climate. The information shall be timely, clear, understandable and available without undue financial burden to the applicant.

11. All human beings have the right to hold and express opinions and to disseminate ideas and information regarding the climate.

12. All human beings have the right to climate and human rights education. This education includes the right to learn from multiple perspectives and to understand non-human natural modes of behavior and the requirements of flourishing planetary ecosystems.

13. All human beings have the right to active, free, and meaningful participation in planning and decision-making activities and processes that may have an impact on the climate. This particularly includes the rights of indigenous peoples, women and other under-represented groups to equality of meaningful participation. This includes the right to a prior assessment of the climate and human rights consequences of proposed actions. This includes the right to equality of hearing and the right for processes to be free of domination by powerful economic actors. This includes the rights of indigenous peoples to participate in the protection of their rights to their lands, territories, natural resources, tenure rights and cultural heritage.

14. All human beings have the right to associate freely and peacefully with others, and to gather peacefully in public spaces, for purposes of protecting the climate or the rights of those affected by climate harm.

15. All human beings have the right to effective remedies and redress in administrative or judicial proceedings for climate harm or the threat or risk of such harm, including modes of compensation, monetary or otherwise.

III:

16. All persons, individually and in association with others, have a moral responsibility to avoid and/or to minimize practices known to contribute to climate damage.

17. All States and business enterprises have a duty to protect the climate and to respect the rights set out in this Declaration.

18. All Parties shall, in all climate change related actions, respect, protect, promote, and fulfil the rights of indigenous peoples. Such rights include support to facilitate mitigation measures; rights to collective self-determination and to 
free, prior and informed consent; to full and equal participation in environmental and political processes; and to respect and protection for indigenous traditional knowledge. This shall include respect and protection for indigenous customary laws, and proper recognition of the role of indigenous peoples in ensuring the integrity and resilience of natural ecosystems.

19. All Parties shall, in all climate change related actions, ensure gender equality and the full and equal participation of women; intergenerational equity; a just transition of the workforce that creates decent work; food sovereignty; and the integrity and resilience of natural ecosystems.

20. All States have a duty to provide assistance and solidarity to climate refugees. States shall respect the rights to assistance and solidarity and create the necessary legal frameworks to assist and support climate refugees in order to ensure their life and dignity.

21. All States shall respect and ensure the right to a secure, healthy and ecologically sound environment and to a stable climate, and ensure the rights outlined in Parts I-III of this Declaration. Accordingly, they shall adopt the administrative, legislative and other measures necessary to effectively implement the rights in this Declaration.

22. All States shall ensure international cooperation with other States and international organizations and agencies for the purpose of respecting the rights outlined in Parts I-III of this Declaration. All States shall observe the rights and duties in this Declaration, including extraterritorially.

23. All international organizations and agencies shall observe the rights and duties in this Declaration, including the human and procedural rights of indigenous peoples, women and other traditionally under-represented and marginalized groups and individuals.

24. All States, international organizations, business enterprises and individuals acting to reduce climate harms shall respect and recognize the rights of any affected human beings and other living beings and systems to be free from climate change-related harm. 